\section{Agata Bielik-Robson}

Instytut Filozofii i Socjologii

Polskiej Akademii Nauk

\title{
Burzliwy żywot amureca, czyli jak Jakub Pannę zdobywał. Słowa Pańskie Jakuba Franka jako powieść łotrzykowska ${ }^{1}$
}

\begin{abstract}
The Stormy Life of Am Ha'arets, or How Jacob Won the Virgin. Jacob Frank's Words of the Lord as a Picaresque Novel
\end{abstract}

The aim of this essay is to present Jacob Frank's Words of the Lord as the first (and perhaps the last) Polish picaresque novel which abounds in semi-fantastical, kabbalahinspired stories, depicting a stormy life of a protagonist who calls himself an "am ha'arets" (a man of the land or a village idiot in Hebrew) and brags of his infinite and supranatural vitality that helps him to overcome all adversities. The essay considers a hypothesis formulated by Yirmiyahu Yovel, according to which the picaro novel emerged in 16th century Spain, in the milieu of the Marranos or conversos, i.e. the Jews who were forced to convert to Christianity, but usually retained some elements of their Judaic faith undercover. This hypothesis seems to fit perfectly well to Jacob Frank's gadki (stories) as he himself can be regarded as the paradigmatic Marrano: a willing convert to Catholicism, whose aim was to "messianize" the Christian religion from within. The essay ends with a comparison of Frank's messianic ambitions to Jacques Derrida whose messianicite operates on a similar Marrano basis.

Słowa kluczowe: frankizm, maranizm, powieść łotrzykowska, żydowski mesjanizm, mesjański witalizm

Keywords: Frankism, Marranism, picaro novel, Jewish messianism, messianic vitalism

1 Artykuł powstał w ramach realizacji grantu NCN „Fenomen maranizmu. Żydowska »tradycja ukryta« i nowoczesność" (UMO-2017/25/B/HS2/02901). 
Gdy Jakób borał się z aniołem, pytał go anioł: Jakóbie dokąd idziesz? Odpowiedział mu: W pole Edoma, to jest do Polski. Mówił on mu: A wiesz też Jakóbie, co tam jest do czynienia w Polszcze? Wszak to i to jest tam do czynienia. Wtenczas wielki strach padł na Jakóba i zemdlał. Naonczas anioł mówił: Nie Jakób jest imię twoje, ale Izrael. Przyjdzie inny Jakób i wykona te uczynki w Polszcze... Jam na tom tylko do Polski przyszedł, abym zgładził wszystkie prawa, wszystkie religie i moim pragnieniem jest, żebym przyprowadził żywot na świat... Grunt podniesienia jest w Polszcze, tam podnieść trzeba.

Słowa Pańskie. Nauki Jakuba Franka z Brna i Offenbachu

Dnia 3 augusta 1657 roku czterech słyszało wielki głos wołający: Chaim, Chaim.

Rękopis frankistowski ${ }^{3}$

Czy jest sens czytać Stowa Pańskie Jakuba Franka jako literaturę, a tym bardziej - literaturę polską? Spisane przedziwną idiosynkratyczną polszczyzną, językiem późno nabytym i półobcym zarówno dla samego mówcy, jak i dla jego kronikarzy, dzieło to stanowi volapük rozmaitych idiomów: obok polskiego także hebrajszczyzny (zapisywanej w alfabecie łacińskim z odczytu w charakterystycznej dykcji aszkenazyjskiej ${ }^{4}$ ) oraz wtrętów z aramejskiego, niemieckiego, frenckiego i ladino. Jakub Frank posługuje się językiem polskim prostacko, kulawo, intuicyjnie, niegramatycznie - $\mathrm{z}$ uporem nie odmienia nazw miejscowych, więc na przykład Częstochowa, miejsce dla niego szczególne, prawie zawsze pojawia się albo $\mathrm{w}$ mianowniku albo $\mathrm{w}$ formie męskiej ${ }^{5}$. A jednak jest to literatura i więcej jeszcze: być może również jedyna polska powieść łotrzykowska. Jedyna i bardzo osobliwa, bo wszystkie te opowieści dziwnej treści, jakimi Frank nas raczy, przeplatając swoją autobiografię baśniowym żywiołem Zoharu, służą wyższemu celowi: wskazaniu na Franka jako na mesjasza, który wyzwoli dzieci Abrahama z oków religijnej tradycji i powiedzie wprost do Królestwa Ezawa, czyli wielkiego nagiego życia ${ }^{6}$.

2 J. Frank, Słowa Pańskie. Nauki Jakuba Franka z Brna i Offenbachu, wstęp i oprac. J. Doktór, Warszawa 2017, s. 54-55, 69, 234. Dalsze cytaty z tego wydania lokalizuję bezpośrednio w tekście, podając w nawiasie numer strony.

3 J. Frank, Rozmaite adnotacje, przypadki, czynności i anegdoty pańskie, red. J. Doktór, Warszawa 1996, s. 55.

4 Dla przykładu: Ecyłos de Ecyłos to aszkenazyjski zapis Acilut de-acilut (,szlachetny nad szlachetnymi”), albo Daas zamiast Da'at („tajemna wiedza”).

5 Na przykład: „Wyści słyszeli, iż Częstochow w ręce królewskie dostał się, a ja z tego nierad jestem, bo moja wola jest, żebyśmy tak sami deptali” (s. 87).

6 Na pokrewieństwo Stów Pańskich z opowieścią pikarejską wskazał już Adam Lipszyc w znakomitym eseju pt. Wyznanie chmary, ze swadą pisząc o ich „chamskich, kipiących przemocą, a przecież i śmiesznych fragmentach [w których - dop. A.B.R.] najwyraź- 


\section{Marańskie łotrzyki}

Asocjację tę - między awanturniczymi proroctwami Franka a narracją łotrzykowską - wzmacnia ich wspólne pochodzenie. Zarówno Frank, jak i pierwsi bohaterowie powieści pikarejskiej są bowiem maranami: potomkami sefardyjskich Żydów, którzy wyszli ze średniowiecznego getta i weszli - pod przymusem bądź dobrowolnie - do społeczności chrześcijańskiej, od początku podejrzewającej, że ukrywają oni swoją żydowskość, jednocześnie potajemnie ją zachowując. Ta zupełnie niezwykła na owe czasy pozycja pograniczna wystawiła maranów na zarzuty „łotrostwa”, ,szachrajstwa” i „krętactwa” z obu stron, zarówno ortodoksyjnie żydowskiej, jak i katolickiej. O ile bowiem dla chrześcijan marani byli ,judaizantami”, oskarżanymi o praktykowanie starej religii po kryjomu, o tyle dla tradycyjnych Żydów stali się ,,chrystianizantami”, którzy oderwali się od surowego kultu prawa, by dać się uwieść proroczym obietnicom Ewangelii, zwłaszcza tym dotyczących życia wiecznego. Ani zatem ich żydostwo nie było tym, z czym mogliby się zidentyfikować pobożni Żydzi, ani ich chrześcijaństwo tym, co wierzący katolik mógłby w pełni uznać za swoje. Ta nieuchwytna z punktu widzenia dobrze zdefiniowanych ról pozycja ani/ani, nieakceptowalna dla ładu społecznego, sprawiła, że marrano dla Żydów nieczysty „wieprz”, dla chrześcijan zaś kryptojudaizant unikający wieprzowiny - zaczął być traktowany jako ,podejrzany typ niewiadomego pochodzenia”, równie niebezpieczny dla systemu jak „fałszywy pieniądz”: łotrzyk, voyou, crook, drobny krętacz, co to „w każdej rzeczy fortelu zażywa” (s. 107) .

Zdaniem Yirmiyahu Yovela, badacza tradycji marańskiej, ta ciągła oscylacja między dwiema ortodoksjami - judaizmem i katolicyzmem - sprawiła, że conversos, czyli „nawróceni”, utkwili w ziemi niczyjej: nie byli już tradycyjnymi Żydami, ale nie stali się też w pełni zintegrowaną częścią chrześcijaństwa. Dla niektórych jednak - a Frank bez wątpienia do nich należy - ta ziemia niczyja przybrała mesjańską postać nowej ziemi obiecanej, okazała się miejscem permanentnego „niedojścia”, a zarazem przestrzenią wolnej negocjacji między różnymi tradycjami, które, oglądane w ten sposób od zewnątrz, mogły po raz pierwszy stać się obiektem radykalnej krytyki. Yovel twierdzi zatem, że to właśnie podmiot marański, który zaadaptował się do kondycji out of joint wytrącenia z kolein ortodoksyjnych tożsamości - jest pierwszym podmiotem nowo-żytnym, a więc też pierwszym podmiotem „nowego życia” (vita nuo-

niej ukazuje się łotrzykowski charakter frankistowskiego mesjanizmu" (idem, Czerwone listy. Eseje frankistowskie o literaturze polskiej, Kraków 2018, s. 31). Mój tekst stanowi rozwinięcie tego świetnego spostrzeżenia.

7 Porównanie marana z voyou, „łotrzykiem”, a następnie z fałszywym pieniądzem w obiegu społecznym pojawia się u Jacques'a Derridy. Zob. idem, Rogues. Two Essays on Reason, transl. P.-A. Brault, Stanford 2005, s. 67. 
$v a$ ), który odkrywa życie jako antynomiczny żywioł poza tradycjami i poza prawem: żywioł „kręty”, „wychodzący z granic od przodków ułożonych” (s. 161), niemieszczący się i rozsadzający każdą prostą drogę ortodoksji. Maran byłby więc pierwszym wcieleniem postaci, którą Friedrich Nietzsche w Tako rzecze Zaratustra nazwie ,żywym głupcem” (der lebende Tor): podmiotem, którego jedyną treścią jest życie samo - życie dopiero co przeżywane, puszczone na żywioł i samo siebie uczące w ciągłej improwizacji. Nietzscheański opis nowożytnego głupka-prostaka z Poza dobrem i złem - „My, nowocześni, my, półbarbarzyńcy dopiero tam zaznajemy naszego błogostanu, gdzie w największym jesteśmy niebezpieczeństwie. Naszą pokusą jest właśnie pokusa nieskończonego, niezmierzonego żywiołu" - znakomicie przystaje do każdego marańskiego łotrzyka, a w szczególności do Franka, z jego antynomicznym zamiłowaniem do szukania zbawienia w niebezpieczeństwie i światła w mroku.

Takim „żywym głupcem”, „półbarbarzyńcą” i „prostakiem” w postaci wzorcowej był picaro, bohater powieści pikarejskiej, która u progu nowożytności zrewolucjonizowała sztukę narracyjną i której korzenie, jak twierdzi Yovel, sięgają właśnie „doświadczenia marańskiego". Pierwszy picaro, XVI-wieczny łazik z Tormesu, bohater anonimowej La vida de Lazarillo de Tormes $y$ de sus fortunas $y$ adversidades ${ }^{10}$, napisanej najprawdopodobniej przez marana, wiedzie śmiałe, pełne przygód życie, które staje się celem samym w sobie, a jednocześnie jedynym tematem autobiograficznej narracji. Jedynym, co interesuje Łazika/Lazarza, jest „to życie”, które - jak sam aluzyjnie stwierdza - odzyskał po tym, jak umarł był jako Żyd, za sprawą śmiertelnego grzechu konwersji wykreślony z Księgi Żywota. Jeśli jednak teraz zmartwych-

8 F. Nietzsche, Poza dobrem i złem, przeł. G. Sowinski, Kraków 2001, s. 151, par. 224.

9 „Najbardziej znane powieści pikarejskie zostały napisane przez conversos, jak Guzman $z$ Alfarache czy Łazik z Tormesu, pierwsza i tworząca gatunek [...]. Obfitują one w rozmaite kody, aluzje i niejawne nawiązania do doświadczenia marańskiego" (Y. Yovel, Spinoza and Other Heretics. The Marrano of Reason, Princeton, N.J., 1989, s. 129). I istotnie, zgodnie z zasadami marańskiej enkrypcji słowa „Żyd” i ,judaizm” nie padają w Łaziku $z$ Tormesu ani razu, pojawia się tam natomiast mnóstwo aluzji - choćby do tych maranów, którzy stronią od Żydów jak od trędowatych, bo tak usilnie nie chcą zobaczyć Żyda w sobie: „Pamiętam - wspomina Lazarillo - gdy pewnego razu mój czarny ojczym zaczął bawić się z dzieckiem, malec, zobaczywszy, że ja i matka jesteśmy biali, a ojciec jego nie, skoczył ze strachem do matki i pokazując nań palcem, rzekł: Mamo, kominiarz! On zaś śmiejąc się, odpowiedział: Ty synu ladacznicy! Choć byłem wówczas całkiem mały, zastanowiły mnie słowa mego braciszka i rzekłem sobie: Iluż to musi być na świecie ludzi, którzy unikają innych dlatego, że nie widzą samych siebie" (Anonim, Żywot Łazika z Tormesu, przeł. M. Mann, Warszawa 1959, s. 7).

10 Żywot Łazika z Tormesu w przekładzie Maurycego Manna ukazał się w Polsce po raz pierwszy w 1923 roku. Na marański kontekst tej powiastki wskazuje także Giancarlo Majorino w świetnej książce pt. At the Margins of the Renaissance. Lazarillo de Tormes and the Picaresque Art of Survival, Pennsylvania 2003, s. 9, 34, 102, 126. 
wstaje, to nie po to, by uwierzyć w chrześcijańskie życie wieczne, lecz tylko w tym celu, by w całości zanurzyć się w życiu doczesnym, materialnym i po brzegi wypełnionym przygodami. Choć więc ciąży na nim ortodoksyjna klątwa Żyda Wiecznego Tułacza, to Łazik obraca ją na swoją korzyść: klątwę błądzenia zamienia w błogosławieństwo „powiększonego życia”. Goethe mówi: „Jeśli chcesz nieskończoności, idź we wszystkie kierunki tego, co skończone” i aforyzm ten, ukuty na użytek Wilhelma Meistra z czasów jego Wanderjahre, doskonale oddaje klimat marańskiej inwestycji w życie doczesne: maran łazik, oddzielony od żydowskiego życia odwleczonego, które cierpliwie czeka na Mesjasza, ale i nie całkiem przyłączony do życia nieśmiertelnego, obiecywanego przez chrześcijan, osadza się mocno tu, na ziemi, i pragnie życia możliwie nieskończonego w danym mu skończonym czasie.

Pokazując blaski i cienie ziemskiego żywota, powieść pikarejska jednocześnie szydzi sobie ze szlachetnego kodu hidalgii, czyli tradycyjnej hiszpańskiej narracji de gestibus, opowiadającej o wzniosłych dziełach. Najlepszą ilustracją tej drwiny jest Don Kichote Miguela Cervantesa, także zresztą podejrzewanego o marańskie pochodzenie, gdzie tytułowy błędny rycerz jest obiektem nieustannych kpin ze strony prostackiego sługi, który - w przeciwieństwie do swego pana - na życiu się zna ${ }^{11}$. Żywioł pikarejski odczarowuje zatem i desublimuje, nie po to jednak - jak twierdzić będą późniejsi romantyczni wrogowie Sancho Pansy - by skończyć w banalnej pochwale cynizmu. Nie o samo bowiem odczarowanie tu chodzi, które pozbawia hidalgo wzniosłości i czyni go śmiesznym. Chodzi o taką desublimację, która pod ośmieszoną ,ruiną praw i tradycji” odnajdzie - u spodu, blisko ziemi - inną ekscytującą formułę nowego zaczarowania: „nowe życie”, uwolnione z gorsetu obcych mu reguł, dzikie i nagie, które teraz uzyska suwerenną podmiotowość - już nauczy się i zarządzi samo, bez formujących go odgórnych nakazów. Picaro, pomimo całego swego deklarowanego prostactwa, barbarzyństwa i cynicznej niewiary we wzniosłe ideały ludzkości, jest więc także - po cichu - „świętym łotrem”, któremu przyświeca mesjański projekt antynomiczny. „Podmiotowość komiczna", którą wzorcowo wciela picaro, funduje nowo-żytność, ale nie tylko w komediowym akcie założycielskim, który śmiechem zabija „,wszystko, co święte"12. Ta profanacja ma swój cel pozytywny, nie mniej w istocie czarowny od tradycyjnego sacrum, choć czar ten nierzadko przybiera groteskową postać pantagruicznego ekscesu, gdzie „to życie” objawia się w nieprzebra-

11 Na temat marańskich kontekstów Don Kichota por. J. Faur, Don Quichotte: un talmudiste au passé souillé, „Pardès. Etudes et culture juives” 2000, no. 29 (Le Juif caché. Marranisme et modernité, ed. S. Trigano), s. 159-168.

12 Por. A. Ochocki, Trzy opery albo podmiotowość komiczna, Warszawa 2003. Adam Lipszyc, który podsunął mi tę pozycję, analizującą komiczne aspekty nowożytnej emancypacji ludu, wspomina, że na seminarium towarzyszącym jej powstawaniu czytany był również Żywot Łazika z Tormesu. 
nym nadmiarze obżarstwa, wyuzdania, transgresji i jak najbardziej zamierzonego upadku w każdy możliwy grzech główny: ten niewyobrażalny nadmiar jest figurą nieskończoności rozsadzającą skończone formy tu i teraz ${ }^{13}$. Kiedy więc Walter Benjamin mówi o Hagadzie, talmudycznym żywiole opowieści, że podnosi ona swą łapę na Halachę, czcigodne prawo i porządek, to ta mesjańsko-antynomiczna zasada doskonale odpowiada marańskiej formułe łotrzykowskiej ${ }^{14}$. Tu faktycznie vida, którą opowiedzieć może tylko arabeskowa forma otwarta - zdolna pomieścić wszystkie poszczególne perypetie, nie narzucając im apriorycznego morału, i niczym wąż kręto pełzająca po ziemi („trzeba pójść na brzuchu do tej rzeczy jak wąż” [s. 216]) - uderza w formułę ogólnego prawa, dobitnie dowodząc, że life is bigger, „życie jest większe”.

Dla Franka wybór formy pikarejskiej jest całkiem intuicyjny. Jego „księga" obfituje w półpornograficzne opisy wywrotowych wyczynów i przygód w licznych krainach: od Podola, skąd pochodził, poprzez Saloniki, gdzie się wkupywał w łaski mieszkających tam sabataistów, po Bukareszt i Warszawę, gdzie się awanturował, Częstochowę, gdzie spędził w więzieniu trzynaście lat, i morawskie Brno, gdzie nieco już podstarzały i schorowany w końcu polecił spisać swoje mądrości. Ich antynomiczny mesjanizm znalazł znakomitą gotową formułę w narracji butnego łotrzyka-chojraka, dla którego nie ma nic świętego i który najchętniej ucieka się do prostych rozwiązań siłowych:

Przyszedłszy raz do bożnicy w Salonice - opowiada Frank w Brnie - gdzie okole 1200 gospodarzy znajdowało się, gdy już tamecznym obrzędem jeden ze szkolników miał przywoływać, żeby ten a ten postąpił do czytania Praw Mojżeszowych na górę, zawołałem mocnym głosem: Niechaj i się żaden tu nie doważy wejść na tę ambonę, bo go tu na miejscu położę. Wszyscy zdziwieni poczęli krzyczeć: Jak to ty masz bronić! Tak ja, powtórnie toż zawoławszy, porwałem pulpit i krzyknąłem, że pierwszego, co się iść waży, tym zamorduję, a potem wziąwszy te Prawa Mojżeszowe położyłem na gołej ziemi i spuściwszy spodnie, usiadłem gołym zadkiem na nich, a wszyscy Żydzi nic nie wskórawszy wyjść musieli (s. 38).

13 Choć sam François Rabelais, ten zdeprawowany mnich, maranem nie był, to zetknął się i zaprzyjaźnił z grupą marańskich wygnańców, którzy osiedli na południu Francji, co, jak dowodzi Christine Escarmant, w istotnym stopniu wpłynęło na jego słynne pantagruiczne wizje, pełne transgresji i ekscesu. Zob. Ch. Escarmant, La lettre marrane de Rabelais, „Pardes. Etudes et culture juives” 2000, no. 29 (Le Juif caché. Marranisme et modernité, ed. S. Trigano), s. 83-102.

14 Uwaga ta odnosi się do hagadycznych parabol Franza Kafki: „Ale ich ubóstwo i piękno tkwi w tym, że chcą być one czymś więcej niż tylko przypowieściami. Nie leżą one u stóp doktryny, tak jak tradycyjna Hagada leży u stóp Halachy. Skulone w wiernopoddańczym przykucu ni stąd, ni zowąd walą w doktrynę ciężką łapą” (W. Benjamin, Selected Writings, vol. 3, ed. M.W. Jennings, Cambridge-Massachusetts 2006, s. 326). 
To jedynie mały fragment barwnej opowieści o poczynaniach młodego Franka na gościnnych występach w Salonikach. Jednak nie sama zabawa kosztem bogobojnych Żydów jest tu celem, choć ta bez wątpienia także, ale też wykonanie „obcego uczynku”, jednego z ma 'asim zarim, w którym chodzi o odwrócenie porządku prawa, by obnażyć jego fałsz; golizna - ,goła ziemia”, „goły tyłek" - to obrazowe synekdochy wielkiego programu antynomicznego obnażania. Frank na tyle dobrze zna Halachę, by wiedzieć, że tak sprofanowany zwój Tory nie będzie się już nadawał do świątynnego użytku i będzie musiał zostać pogrzebany w genizie („U Żydów zwyczajem wyprawiać pargamin na prawa psim łajnem, na ostatku wyprawią je człowieczym gównem, aby skasowane zostały" [s. 217]). Im więcej zatem Tor Frank wysmaruje gównem, tym szybciej uda mu się skończyć ze skandalem, jakim jest jarzmo prawa i religijny kult w Templu. Oprócz zatem golizny, którą otwarcie pochwala jako „znak na przyszłość” (s. 351), apokaliptycznego obnażenia nagiej prawdy (i dlatego podoba mu się, że w przeciwieństwie do „zawiniętych i zakrytych” panien muzułmańskich, ,w stanie edomskim [...] kobiety noszą same włosy i piersi też odkryte" [s. 351]), drugim ulubionym rejestrem ,dziwnych poczynań" Franka jest właśnie skatologia. Kiedy indziej opowiada, jak ukradł kielich rytualny, ,wyjął z niego perfumy i nakładł gówien - w wieczór oni wszyscy odmawiali błogosławieństwa nad tym i do nosa przytykali te paskudztwa jeden po drugim" (s. 117). Znów nie chodzi wyłącznie o dobry kawał, ale o to, by wywołać świętą wojnę:

Mocnymi tymi uczynkami zrażone kobiety żydowskie zaczaiły się pewnego wieczora w jednej ulicy na mnie, każda mając chustkę naładowaną kamieniami, ja idę, one stały sypać na mnie grad kamieni, ja nic nie mówiąc pozbierałem też same kamienie i nimiż jak stałem na nich walić, to niektóre ciężarne poroniły natychmiast, wiele pomdlały, wiele poranionych zostało, jęk i krzyk po całej rozlegał się ulicy, a jam sobie do domu poszedł (s. 38-39).

Obraz kobiet roniących ,natychmiast” pod gradem mesjańskich kamieni to dobra próbka tej szokującej chamskiej „obcości” - marańsko-pikarejskiego ośmieszającego Verfremdungseffekt - którą naszpikowane są Frankowe „gadki”. Potem następuje długa opowieść o tym, jak Żydzi „wszystkich oberżystów w Salonice umawiają i przekupują, aby mnie sami zabili, gdy przenocować przyjdę" (s. 39) i jak im się to nie udaje: Frank, żywotny prostak i niespożyty łazik, na przekór wszystkim żyje dalej i ,jedzie w swoją drogę" (s. 39), wiedziony jedną ambicją, by „dojść do żywota”. Ten żywot, który pragnie tylko więcej samego siebie - la chaim, „więcej życia” - zamyka się zatem w tysiąc i jednej opowieści, gdzie mesjańska megalomania i narcyzm przeplatają się z naiwnym samochwalstwem i poczuciem wybraństwa, którego w gruncie rzeczy nie uzasadnia nic oprócz wyjątkowo silnej i asertywnej świadomości własnego życia. Frank nic nie wie, niewiele rozumie, sam uważa 
się za prostaka i chama, ale ma w ręku jeden argument, który jest dla niego nie do zbicia: żyje i chce żyć. To niewyobcowywalne prawo, które w jego hiperwitalnej wyobraźni urasta do rangi mesjańskiej:

Wszystkie religie, wszystkie prawa, wszystkie księgi, które były dotąd, i ten, kto je czyta, to rychtyk jakby twarz w zad obracał i wglądał w słowa, które już dawno poumierały. Wszystko to wychodziło od śmiertelnej strony (s. 51).

Widzicie mnie przed sobą, prostaka, stąd wam wnieść należało, iż wszystkie prawa i nauki upadną, gdyby potrzebowano uczonych, to by wam posłali takiego, co świadom wszystkiego (s. 58).

Ten absolutny prymat życia - mojego małego własnego ,ja jestem" - nad wszelkim prawem, wartością i ideałem, stworzonymi i chronionymi przez martwe archiwa, to charakterystyczna cecha powieści łotrzykowskiej, która rzuca wyzwanie każdej tradycji: mogę być małym, nic nieznaczącym prostakiem, ale żyję - podczas gdy wy, czcigodni twórcy praw, już od dawna gryziecie ziemię. To właśnie ten wyzywający rys sprawi, że z narracyjnej formy pikarejskiej skorzysta wielu Żydów, którym nieobce było „marańskie doświadczenie" pogranicza wielu tradycji, prowadzące do subwersji tradycji jako takiej ${ }^{15}$. To nie przypadek zatem, że formę tę przyjął Ilja Erenburg w Burzliwym życiu Lejzorka Rojtszwańca (pierwotnie właśnie Lasika, czyli po rosyjsku „Lazarka”), powieści opowiadającej o losach „małego Żydka” wytrąconego ze swojej sztetlowej wspólnoty i wrzuconego w tryby sowieckiego molocha, który jednak jakoś sobie radzi i z każdej biurokratycznej opresji wychodzi łatwo, choć i bez większych sukcesów. Dalej Saul Bellow w Przypadkach Augie'ego Marcha: również i tu chicagowska szajka żydowska wiedzie swój bujny półlegalny żywot na marginesie białej chrześcijańskiej Ameryki, jednocześnie z pogardą odnosząc się do „tych z jesziwy”. Ale także Philipa Rotha czy to Kompleks Portnoya, z brawurowym opisem przygód i podbojów erotycznych, czy z zamierzenia komiczny i odczarowujący Zuckerman Unbound, jako zdesublimowana wersja wzniosłej tragedii Percy'ego Shelleya o Prometeuszu, dobrze się wpisują w narrację marańskiej wszechprześmiewczej konwencji, która jednak, dzięki namiętnemu umiłowaniu życia ze wszystkimi jego blaskami i cieniami, nie utyka w cynizmie. We wszystkich tych

15 Lipszyc sugeruje, by w tej perspektywie czytać również Autobiografie Salomona Majmona: „Ten powiew nowoczesności wyczuwalny w żywocie i poglądach Jakuba Franka byłby zresztą niezłym pretekstem, by jego karierę zestawić z inną, także po trosze łotrzykowską opowieścią o wyjściu z żydowskiego świata, a mianowicie z fascynującą autobiografią filozofa-racjonalisty Salomona Majmona" (A. Lipszyc, op.cit., s. 32). Por. S. Majmon, Autobiografia, przeł. L. Belmont, red. B. Szwarcman-Czarnota, P. Paziński, Warszawa 2007. 
przypadkach mamy do czynienia z wędrowcami, czy raczej, mniej patetycznie, włóczęgami, którzy wyszli, ale nie doszli, i którzy pozostają w ciągłym, niespokojnym Ruchu: ruchu nieustannego „borania się” - agonu z tradycjami, ortodoksjami, prawem, tożsamością, państwem - będącego treścią i sednem „nowego życia”"16.

\section{Prowokacje amureca, czyli jak teologizuje się młotem}

W jakim stopniu Frank jest takim marańskim „łotrzykiem”, picaro, voyou, dla którego życie - jego własne życie tu i teraz - staje się jedyną sprawą? Pisząc o maranach jako prekursorach przemian nowożytnych, Yovel akcentuje marańskie odkrycie doczesności:

Istotą doświadczenia marańskiego jest: decentracja religii, emancypacja znaczących fragmentów życia spod religijnej kontroli, blaknięcie sacrum, utrata zaufania do tradycyjnych pośredników lączących jednostkę z tym, co boskie, ogólny zanik wiary i wyłonienie się sceptycyzmu. Wszystko to z kolei przyczynia się do: autoasercji jednostki wobec ustanowionych tradycji, przewartościowania społecznych wartości, a także do mniej lub bardziej eksplicitnej inwestycji w „filozofię immanencji” [...]. Doczesne sprawy tego świata - saeculum - zyskują odrębną ważkość i ważność. Jednostki nie postrzegają już swego życie na ziemi jako „przebytu”,

16 Termin „Ruch” a także „Partia Ruchu” pochodzi od Mosesa Hessa, twórcy mistycznego syjonizmu, który w swojej Świętej historii ludzkości, napisanej w roku 1837, kreśli synkretyczną - i w istocie całkiem marańską - panoramę duchowego rozwoju człowieka, stanowiącą żydowsko-mesjańską wariację opartą na schemacie heglowskim. Ruch - nieważne czego i do czego - sam w sobie i jako taki jest najcenniejszą iskrą ukrytą w skorupach dziejowego Bezruchu/Spokoju i nawet jeśli jej wyzwolenie wiąże się z przemocą, jak to było w czasie rewolucji przemysłowej czy rewolucji francuskiej, to trudno - lepsze to niż tkwienie w martwym marazmie. O wczesnonowożytnej migracji ludu pisze więc Hess na sposób, który świetnie pasuje do Ruchu Franka, bo też korzysta z archiwum żydowskiego antynomizmu: „Chylimy czapki przed tym wielkim ruchem, jaki ogarnął ziemię, kiedy to dzikie masy, przypominające ochłapy surowego mięsa, w niczym zaś szlachetnych panów, wyłoniły się nagle jak ślepe siły natury - jednocześnie zdeterminowane, by odmłodzić duch chrześcijaństwa [...]. Dusze słabe, które zawsze pływają po powierzchni, bo brak im oddechu, by wziąć głębokiego nurka, lamentują nad okropieństwami Wielkiej Rewolucji Francuskiej. My zaś rozpoznajemy majestat Boga nie tylko w przyjaznym blasku słońca, ale także w groźnej burzy; nie tylko w bujnie owocującym ogrodzie, ale i w zlanym krwią polu bitwy. Pedanci unikają Człowieka Ruchu, nie zdając sobie sprawy, że w całej ludzkości to potężne poruszenie życia musi w końcu wydać z siebie coś wartościowego i że tym, co opóźnia odrodzenie, jest właśnie próżna idolatria zakrzepłej i umarłej tradycji” (M. Hess, The Holy History of Mankind and Other Writings, transl.. S. Avineri, Cambridge 2004, s. 23, 40; wyróżn. moje - A.B.R.). 
który przygotowuje ich do świata przyszłego, nie postrzegają też życia w Bogu, boskiej prawdzie i służenia jego woli w ramach religijnego kultu jako jedynego uzasadnienia dla ich ziemskiej egzystencji. Świat - ten świat, zawierający ludzkie życie, działania i osiągnięcia - nie jest już doświadczany jako rzeczywistość wybrakowana, ani też jako pokusa: świat doczesny staje się prawomocny sam w sobie ${ }^{17}$.

Gershom Scholem z kolei, analizując marańską teologię potomków Szabtaja Cwi (przez Franka zwanego Signor Santo bądź Pierwszym), wskazuje, z pozoru antytetycznie do Yovela, na pogłębienie wymiaru duchowego, który internalizuje się - i okopuje - w postaci niekomunikowalnego sekretu:

Psychologia radykalnego sabatianizmu była dogłębnie paradoksalna i „,maraniczna”. Jej główną zasadą było: ktokolwiek jest tylko tym, czym się wydaje, ten nie może być prawdziwym ,wiernym”. W praktyce oznaczało to, że ,prawdziwa wiara" nie może być tym, co ludzie głoszą publicznie. Przeciwnie, ,prawdziwa wiara” musi być zawsze ukryta. W istocie „wierny” powinien się jej wypierać, ponieważ wiara ta jest jak ziarno zasiane na dnie duszy, które nie może wzrosnąć, jeśli najpierw nie zostanie zakryte. Z tego też powodu każdy Żyd jest zobowiązany do tego, by stać się maranem ${ }^{18}$.

Frank, który często ucieka się do marańskich autodeklaracji:

Ja byłem prostak i nie wiedziałem, kiedy Sabbath przypada, bom mieszkał pomiędzu chrześcijanami, tylko mi kobieta jedna co piątek w wieczór przynosiła kołacze, stąd wiedziałem, że jutro Sabbath będzie: rozumiałem, że te kołacze to jest Sabbath (s. 221).

- wydaje się spełniać obie definicje: i Yovela, podkreślającego sekularny wymiar marańskiej duchowości nakierowanej na świat doczesny (słodkie kołacze!), i Scholema, stawiającego nacisk na wyższość sekretu nad religią jawną. Frankizm jednocześnie bowiem ukrywa sekretne jądro zwane Daas, ,wiedzą

17 Y. Yovel, The Other Within. The Marranos: Split Identity and Emerging Modernity, Princeton-Oxford 2009, s. 353 (wyróżn. moje - A.B.R.).

18 G. Scholem, The Messianic Idea in Judaism. And Other Essays on Jewish Spirituality, New York 1995, s. 109 (wyróżn. moje - A.B.R.). Istotne, zważywszy na sabatajskie wejście w krainę islamu, jest to, że kafar, czyli „heretyk” po arabsku, oznacza dosłownie „zakrytego", czyli takiego, u którego światło wiary ukrywa się pod ciemnymi warstwami ignorancji. Marańska inwersja antynomiczna przewraca ten obraz do góry nogami: kiedy światło staje się ziarnem, potrzebuje ciemności i chtonicznego elementu ziemi, by wzrosnąć. 
tajemną”, nad którą ciąży ma'as duma, czyli „ciężar milczenia”19, i rzeczywiście traktuje ją jak ziarno, które się ,flancuje” na dnie duszy, by wśród ciszy i ciemności spokojnie wzrosło. Zarazem upatruje sedna tej gnozy w „dojściu do żywota”, który bynajmniej nie oznacza bezcielesnej, czysto duchowej nieśmiertelności, lecz nieskończoną intensywność życia tu i teraz, proroczo antycypowaną przez liczne przygody i awantury samego Franka, w istocie tak liczne i penetrujące ,wszystkie kierunki tego, co skończone”, że trudno sobie wyobrazić (ale i o to chodzi), by mogła je pomieścić pojedyncza ludzka egzystencja. Frankizm więc godzi obie perspektywy, Yovela i Scholema, będąc nie tyle „filozofią immanencji” (jak to się stało w przypadku marana Spinozy), ile niezwykle intensywną t e olog i ą d oc z e s ności, gdzie sens wszystkich religii objawionych - ukryte ziarno wciąż oczekujące na wzrośnięcie - polega tylko na jednym: na obietnicy ,życia powiększonego", la chaim. Słowa pańskie... co i rusz zadają profetyczne pytanie, które wskazywać ma właśnie na Franka jako tego ostatniego w mesjańskiej linii, który sprawę zak ońc z y: „K to to jest ten, co pójdzie na ten świat, aby przyprowadził żywot wieczny na ten świat?” (s. 389) ${ }^{20}$. Także liczne ,gadki”, jak sam Frank nazywał swoje opowiastki-parabole, utrzymane w stylu pikarejskim, pouczają słuchaczy, że nie w mistycznych wzlotach droga, lecz w przyziemnym i namacalnym spełnieniu witalnej obietnicy:

Będąc pierwszy raz w Romaniu, powracając z Saloniki u ojca mego z tymi dwoma, z Rabbi Nussen i Jakubowskim, bawiliśmy tak dni kilka. Jakubowski mówił do ojca mego: Ja idę z tak kosztownego miejsca (w Salonikach przebywała sabatajska sekta donmeh, której przewodził Drugi, czyli Baruchia Russo - A.B.R.), a dziwię się tobie, że ty, taki wielki będąc człowiek, nie wypytujesz mię o naukach i tym podobnych wiadomościach, com tam nabył. Odpowiedział mu: Zaprawdę powiadam ci, że mi nic z tego nie przychodzi, choć mi odkryjesz, że jest jarmark na

19 Na temat sekretu patrz świetny wstęp Jana Doktóra do zbioru Stów Pańskich: J. Doktór, Nieznośny ciężar milczenia [w:] J. Frank, Słowa Pańskie..., s. 9-32.

20 Program „skasowania religii” (s. 313) za pomocą „obcych uczynków”, które odwracają, a przez to niszczą uświęcone prawa (obżeranie się mięsem, w tym zwłaszcza wieprzowiną, i nabiałem jednocześnie, jawne podróżowanie w szabas, podcieranie sobie tyłka zwojami Tory, by uczynić je niezdatnymi do dalszego użytku, etc.; wszystkie te subwersje przewijają się wielokrotnie we Frankowej narracji), jest samym sercem frankistowskiego antynomizmu, co, zdaniem Giorgia Agambena, stanowi jednocześnie sedno interwencji mesjańskiej jako tej, która przychodzi, by „zakończyć sprawę”: „Zarówno w judaizmie, jak w chrześcijaństwie czy islamie, mesjańskie wydarzenie oznacza kryzys i radykalną transformację całego porządku prawa. [...] Królestwo Mesjańskie nie jest więc tylko jedną z kategorii religijnego doświadczenia, ale jego pojęciem granicznym. Mesjasz to figura, w której religia napotyka problem prawa i dokonuje z nim radykalnego obrachunku" (G. Agamben, Potentialities. Collected Essays in Philosophy, transl. D. Heller-Roazen, Stanford 2000, s. 162). 
niebie. Co stąd wyjąć mogę i co stąd za mądrość dostanę? W moich oczach to jest głupstwem. Mów mi raczej, co się tu będzie działo, na tym świecie, żebym oczyma mymi widział te wielkie czynności, co Bóg tu ma działać na świecie, to bym się cieszył (s. 352).

Frank podpisuje się pod antymistyczną ziemską mądrością swojego ojca, upominając wyznawców: ,Wy sami widzicie teraz, jak ciało nasze uchylone i prawie przyciśnione do ziemi; lecz ja nie patrzę na niebo, żeby i stamtąd pomoc przyszła, tylko patrzę co Bóg tu uczyni na ziemi, na tym świecie” (s. 326). Wbrew zatem wszelkim mądrościom uczonych w piśmie i ich mistycznym komentarzom obietnica nie należy do „piśmienników” - a tylko do prostaka, człowieka ziemi, amureca (am-ha 'arec), który odważa się odrzucić i obśmiać ich nauki, nazywając je wprost ,głupstwem”. Ażeby obietnica ta, ukryta pod płaszczami uczonych religii, wyszła na jaw, trzeba wykonać ten prostacki, profaniczny i łotrowski gest: zostawić niebo wróblom i mocno okopać się na ziemi. „Czemuście po mnie nie poznali - żali się Frank swoim niepojętnym słuchaczom - gdym przyszedł bez nauk, że ja chcę wszystko na jawie wyprowadzić, nie tak jak przodkowie, którzy tylko słowami mówili?” (s. 207). Do przodków należą tu nie tylko prawowierni Żydzi, ale także Jezus, wielki - niestety - „piśmiennik”, który swą uczonością wszystko zepsuł:

Ten Chrystus jest przedmową, która jest głupstwem i to jest przed owocem. Przyszedł dopiero okazać mądrość, która ma wyjść i wielką rzecz on sam byłby wyprowadził na świecie, żeby był nie sfałszował poselstwa swego, a gdyby był między faryzeusze nie szedł nauki dawać, byłby dobrze uczynił (s. 232).

Jeśli jednak obietnica wielkiego życia nadal pozostaje niejawna, przykryta złogami fałszywej uczoności, to dlatego, że wyszła ona od Boga Ukrytego, który wycofał się w akcie kontrakcji, cimcum: kabalistycznego Ein-Sof, pierwotnego Boga ,bez kresu”, co oznacza również bez de-finicji i bez jawnego imienia. To on, jako pierwszy, bezimienny i ukryty, jest prawdziwie szczodrobliwym dawcą życia, którym obdarowuje swoje stworzenie, niczego nie oczekując w zamian. Wszyscy inni - już określeni i imienni - bogowie są w porównaniu z nim bogami fałszywymi, a w tym sensie idolami: gdy tylko pojawia się Imię, samookreślenie, tożsamość, widzialność - natychmiast też rodzi się narcystyczne żądanie kultu i posłuszeństwa; nastaje religia instytucjonalna z całym kodeksem kultowych zachowań, których celem jest czcić Ha-Szem, wielkie zazdrosne imię nakazujące nie mieć żadnych innych bogów ,przede mną”. Ein-Sof to otchłanny bezkres, któremu ta narcystyczna zazdrość jest całkowicie obca, dlatego też nie powołuje w istocie żadnej religii jako systemu zadłużenia i zwrotu, w którym wierny musi się odpłacić swemu Bogu i uhonorować jego imię. Frank, jako typowy maran, jest pozbawiony de-nominacji, dlatego też bliżej mu do Boga-(jeszcze)-bez-Imienia, który wy- 
cofuje się i chowa, by zrobić miejsce stworzeniu, nie domagając się żadnego specjalnego kultu. To Bóg, który daje życie w akcie czystego obdarowania, nie zadłużając swojego stworzenia poczuciem pierwotnej winy: grzechu pierworodnego, które naznacza wszystko, co żyje, źródłowym wrodzonym brakiem. Dzięki temu czystemu darowi, życie dane przez Ein-Sof może być wreszcie „życiem w całości”: życiem niewybrakowanym i niepokaranym apriorycznie przez śmierć. Tako rzecze Frank:

Wy zaś bylibyście pierwszymi, co byście się zwali ludźmi w całości, a nie Enysz (enosz, człowiek), jak było w dawnych latach. Nim Adam był stworzony, to wierzono w nie mającym gruntu Ensoph, nie nazwano zaś żadne miejsce bóstwem póki nie przyszedł jeden i stworzył Adama, i przez niego wszystko zepsuło się, i ziemia została w klątwie (s. 381-382).

Ten „Jeden” - Adonai echad, czyli Pan Jedyny żydowskiego monoteizmu, odziedziczony przez chrześcijaństwo i islam - nie jest Bogiem prawdziwym, lecz uzurpatorem albo, jak to określa tradycja gnostycka, archontem (Frank nazywa go wręcz „komisarzem”, zaś Adam Mickiewicz - częściowo ustami Konrada, a częściowo demonów - ,carem”), który tworzy wadliwego, wybrakowanego Adama: „Świat i Adam nie są stworzeni od żywego Boga, dlatego każdy musi umierać i świat się nie utrzymuje, bo jest stworzony od komisarzy. Ale Bóg mój żywy i dobry chce ustawić świat w stałości” (s. 392). Wybrakowany śmiertelny Adam nie potrafi ani ,żyć w całości”, ani „utrzymać się w stałości": potrzebuje zewnętrznego sztafażu prawa, które uzupełni brak życia jako korekcyjny suplement albo proteza dla kalekiego stworzenia. „Bóg [prawdziwy - dop. A.B.R.] powiedział Abrahamowi: Tobie i dzieciom twoim dam te wszystkie kraje. Nie mówił On, że da im prawa [...]. Wszyscy, co nie mają Boga, bodaj by się oni praw uczyli" (s. 382). Prawo jest formą ściśle zewnętrzną, czymś w rodzaju egzoszkieletu podtrzymującego wybrakowane życie, które nie potrafi przeżyć bez prawa samodzielnie; jest skorupą, w której ziarno życia się przechowuje, ale tylko w postaci przetrwalnikowej, zdeformowanej, niedokończonej. Prawo jest suplementem życia naznaczonego brakiem, nie-do-tworzonego do końca, albo - jakby powiedział Norwid - ,potworzonego": jednocześnie umożliwia przetrwanie, ale tylko przetrwanie, nic więcej. Nie daje wzrosnąc ziarnu; chroniąc je, zarazem je tłamsi i zatruwa winą, grzechem, powinnością, a w końcu śmiercią jako karą ostateczną - całym tym odium prawa, które zabija życie przez Boga Pierwszego, ,żywego i dobrego”, zamyślone „ku niewinności”: „Lepiej było wam jeść błoto, jak prawa mówić tu w tym miejscu, bo prawo dane dla obciążliwości i powinności, i one osłabiają moc człowieczą" (s. 379). Oferując możliwość p r ze ży c i a istocie wybrakowanej, jednocześnie odbiera jej szansę na ży c ie w całości: korzystanie z daru, którego szczodrobliwie i bezinteresownie udziela tylko Bóg prawdziwy, ukryty i niewidzialny Ein-Sof. 
Prawdziwy Bóg odkryć się nie może na tym świecie, tak jest w istocie, bo świat ten cały zepsuty i nic w nim dlatego nie ma (s. 125).

Od początkowego stworzenia wszelka tam dobroć zachowana w granicach jego, bo tam ziemia nie jest przeklęta i jest pomiędzy światami, które w przeklęstwie zostają, zagroda i zasłona od tamtych, tam jest wszystko, co serce człowieka żąda, zakosztować pieczystego, zwierząt, ptactw tłustych, chleba białego, wszystko ziemia sama z siebie wydaje w jednym oka mgnieniu. Zawsze jego pragnieniem jest widzieć i zjednać się z ludźmi tymi, co na tym tu świecie mieszkają. On wie o mnie, że ja tu powstałem na świecie, i wie, że ja sam się trudzę i uganiam za jakąwoś dobrą rzeczą [...], jednakże choć on w bóstwie, nie wie atoli, jakim sposobem i mocą przestąpić granicę, aby tu mógł być między nami, bo ta przegroda jest od początku. [...] Ogrody moje, winnice moje, aby ze wszem tak rośli, jak u niego, i co byście wy tylko żądali od niego, dałbym wam to, to jest: wzrost, piękność, mądrość, moc, żywot, bogactwa (s. 152-153).

W teraźniejszym czasie wszystkie członki próżnują, lecz gdy przyjdę do tej rzeczy, za którą ja się uganiam, wówczas wszystkie członki będą ku usłudze; uszy będą słyszeć, oczy będą widzieć, a ręce podniosą swoje (s. 398).

Żeby jednak odzyskać tę pełnię obecności ukrytego Boga Zza Zasłony, trzeba zstąpić w same doły: w krainę pokrywy i skorupy, w której zakrzepłe prawo jednocześnie skrywa, chroni i dławi ziarno życia, nie pozwalając mu na to, by wzrosły ogrody i winnice wielkiego żywota. Dlatego ten, który ,przyprowadzi żywot wieczny na ten świat” (s. 389), musi być jednocześnie Mesjaszem, który „musi pójść do przepaści i wejść musi do Edom [...] dla wielkiej świętości” (s. 173). Zgodnie bowiem z nauczaniem kabały, najmocniejsze iskry-ziarna, które obiecują najwięcej życia, znajdują się pod najcięższymi pokrywami, na samym dole stworzenia, czyli ,w piętach Adama”. Dla Franka tą najcięższą skorupą, gdzie iskry w pięty poszły, nie jest jednak judaizm, który skądinąd odrzuca on jako religię prawa i śmierci, ani chrześcijaństwo reformowane, którego mesjański zapał zna z kontaktów z menonickimi misjonarzami na wschodnich rubieżach Polski, lecz katolicyzm, „religia edomicka”, zwłaszcza w polskim wydaniu.

Franka wizja polskiego katolicyzmu antycypuje późniejsze teorie Zygmunta Krasińskiego, Stanisława Brzozowskiego i Romana Dmowskiego, którzy postrzegać będą religię katolicką jako absolutnie martwą formę narzucaną życiu z pozycji suwerennego i prawodawcznego zewnętrza: religię niemistycznej transcendencji, do której nie można się zbliżyć, a której należy być skrupulatnie, po jezuicku, posłusznym, przyjmując ją jako skończoną forma vitae. Dla Franka katolicyzm to ostateczna mądrość skorupy, w której, w postaci niejawnej, wyraża się prawda o uciśnionym życiu. Tam bowiem, gdzie 
rośnie niebezpieczeństwo, wzrasta również szansa na zbawienie: najpotężniejsza skorupa Wielkiego Brata więzi najżywotniejsze iskry. Zamiast więc tradycyjnego Exodusu jako Wyjścia z Egiptu, Frank głosi ruch odwrotny: „wyjście z Kanaan do Egiptu", gdzie - w symbolicznym domu niewoli - leży pogrzebana najjaśniejsza cząstka boskiego ognia: Skarb, Rzecz, Sprawa.

Gdybym wythumaczył Żydom, co to znaczy: idź, idź z swego kraju (lek lekcha: Rdz $12,1)$, to by wszyscy poszli za mną do chrztu z wielką radością [...]. Jakób nie mógł mówić to słowo: To czyńcie i żyjcie (Łk 10, 29), bo jeszcze nie był w Egipcie, tylko w Kanaan. Dlatego więcej nie mówił, jak te dwa słowa: To czyńcie (Rdz 43, 11). Lecz Józef był w Egipcie i zwał się tym imieniem: młody król, myślał, że on wszystko zakończy, dlatego mowił: To czyńcie i żyjcie. [...] Bóg to wszystko czynił swymi sposobami, że oni przymuszonymi byli zejść do Egiptu (s. 209, 377) ${ }^{21}$.

Tam więc trzeba iść i nie ustawać w trudach tej najeżonej przeciwnościami (adversidados) powieści drogi: „pójść w cudze miejsca” i czynić tam ma 'asim zorim, dziwaczne „cudze uczynki” (s. 154), które wszystko wywracają na nice; deptać, kruszyć, rozwalać skałę i kuć. „Mówiłem wam: Póki wasze królestwa wspak zwrócone zostana. I wy widzicie własnymi oczyma, jak wszystkie religie odmienione i wychodzą z granic od przodków ułożonych" (s. 161). Oto jak teologizuje się młotem. Gdyby Nietzsche miał więcej poczucia humoru i naprawdę był tym „półbarbarzyńcą”, którym tak bardzo chciał się stać, a nie patetycznym „niemieckim myślicielem”, to napisałby swojego Zaratustrę w przygodowej i bezbożnej formule narracji pikarejskiej, która Frankowi, ,świętemu łotrzykowi”, przyszła zupełnie bez trudu.

\section{Rewolucja prostaków, czyli Panna i Wielki Fallus}

Pisząc o stylu Karola Marksa, który nauczył się angielskiego, by przemawiać wprost do brytyjskiego proletariatu - tego wyklętego ludu ziemi, mającego spełnić jego rewolucyjne nadzieje - Marshall Berman określa go jako „awkward but powerful”, „koślawy, lecz potężny”22. Taka jest też polszczyzna

21 Figura „wyjścia do Egiptu” pojawia się także w finale Ulissesa Jamesa Joyce’a, kiedy Leopold Bloom - najsłynniejszy maran literacki - razem ze Stefanem Dedalusem wyśpiewują po łacinie, kompletnie zalani, psalm 113 na cześć Exodusu i, jakby się wydawało, popełniają zwykły pijacki błąd. Kto wie jednak, czy Joyce, niewiarygodnie oczytany w tekstach ezoterycznych wszelkiej maści, nie znał również elementów doktryny frankistowskiej?

22 M. Berman, All That is Solid Melts into Air. The Experience of Modernity, London s. 19 (przekład polski: M. Berman, ,Wszystko, co stałe, rozplywa się w powietrzu”. Rzecz o doświadczeniu nowoczesności, przeł. M. Szuster, wstęp A. Bielik-Robson, Kraków 
Franka, z jaką zwraca się on do swoich owiec w nadziei, że przemienią się w Ezawowe wilki, odziane w „strój, za pomocą którego padnie bojaźń na zwierzęta" (s. 183). To skojarzenie z Marksem, zwłaszcza z okresu Manifestu komunistycznego, wcale nie jest przypadkowe. Tak bowiem jak Marks pisze manifest człowieka nowoczesnego jako nowego podmiotu uwolnionego z zakrzepłych feudalnych stosunków, który wyruszył w świat w poszukiwaniu innego życia - tak Frank jest jednocześnie katalizatorem i świadkiem analogicznego Ruchu, dzięki któremu cała ludzkość ostatecznie strząśnie z siebie jarzmo praw, religii, tradycji i świętych hierarchii, by na koniec „dojść do żywota”. I tak jak Marks pisze o wielkiej rzeszy chłopów, którzy za sprawą rewolucji przemysłowej przez chwilę choćby poczuli się ludźmi wolnymi i ruszyli do miast - tak Frank, sam zdeklarowany prostak-amurec, kilka dekad wcześniej kreśli podobną wizję emancypacji uciśnionego ludu ziemi ze szczególnym naciskiem położonym na jego witalne ,podziemne potęgi”, unterirdische Kräfte $e^{23}$. Nawet więc jeśli Marks wybiera idiom skrajnego odczarowania, a Frank mówi z głębin kabalistycznych baśni, to Marksowska diagnoza, że w nowoczesności „wszystko, co stałe wyparowuje i wszystko, co święte ulega profanacji”, stosuje się z powodzeniem do Stów Pańskich ${ }^{24}$. O ile jednak Marks odczarowuje religijne „świątobliwe dreszcze pobożnej egzaltacji"25 z pozycji zewnętrznej, o tyle Frank dekonstruuje język religijny od wewnątrz, pokazując, że ruch ziemskiej profanacji należy do jego własnej dynamiki, a nawet stanowi samo sedno obietnicy objawienia, którą zafałszowała ludzka słabość. Słabość przybierająca postać tradycyjnej, miałkiej pobożności, której „egzaltacje” w istocie bardziej przystoją tępo posłusznemu psu:

[...] wszelka żywność idzie z ziemi, również i my na ziemię patrzeć powinni (s. 72).

Zaprawdę zaś, grunt od korzenia w ziemi, dlatego nie trzeba do góry patrzeć, tak jak kiedy psu żreć dają, to on pogląda w górę. Ja chciałem się chwycić gruntu korzenia, wy byście wówczas chwycili się mnie i wszyscy trzymalibyśmy się żywego drzewa [...] (s. 226).

2006). Berman, wielki zwolennik „modernizmu przygody”, sam w swojej eseistyce chętnie używa stylu pikarejskiego, dzięki czemu nawet Kapitał Marksa może się wydać powieścią płaszcza i szpady.

23 Por. K. Marks, F. Engels, Manifest komunistyczny, przeł. W. Piekarski [w:] eidem, Dzieła, t. IV, Warszawa 1962, s. 646.

24 „Wszystko, co stanowe i zakrzepłe, znika, wszystko, co święte, ulega sprofanowaniu i ludzie muszą wreszcie spojrzeć trzeźwym okiem na swoją pozycję życiową" (ibidem, s. 643; wyróżn. moje - A.B.R.).

25 Ibidem, s. 641. 


\section{Prawda z ziemi wyrośnie (s. 330) ${ }^{26}$.}

Wprowadzając motyw „podziemnych potęg”, Marks odwołuje się do jeszcze jednej metafory - ucznia czarnoksiężnika, który rozpętuje karnawał chtonicznych mocy, ale nie zna zaklęcia odczyniającego - by zobrazować rewolucyjny Ruch, którego nikt i nic nie zdoła już powstrzymać. Frank ma podobne poczucie: jako niedouczony prostak uwalnia widma apokalipsy, które zaczynają krążyć nad Europą, w miarę jak on i jego wyznawcy krążą po Europie, i pozostawia swoje destrukcyjne dzieło w przekonaniu, że prędzej czy później wywiąże się „wojna narodów” i poleje krew. Polscy Żydzi i polscy katolicy, mieszkańcy polskiego Edomu - owej wielkiej „łupy”, w której ukrywa się nowy Ezaw - mają bowiem pod wpływem jego proroczych słów doznać przemiany, która zapoczątkuje wielką mistyczną rewolucję. Wszelkie prawa, tradycje, synagogi i kościoły upadną jako te nic nieznaczące „łuspiny”, by spod ich ruin zmartwychwstać mogło życie samo, jakiego nikt jeszcze nigdy nie zaznał. Życie dzikie, nagie, nieokiełznane, popędowe i anarchiczne życie Ezawa myśliwego, rudego brutala odzianego w zwierzęcą skórę, albo, jak by powiedział William Blake, Ognistego Tygrysa, który suwerennie włada całym stworzeniem, nie mając nad sobą nikogo ani niczego - to wielkie Życie, potężnym głosem wołające, którego Frank widzi się prorokiem. Szokuje więc i drażni swoje wciąż zbyt pokorne, zbyt posłuszne owieczki, by poczuły w sobie tę zwierzęcą libidinalną moc, stłumioną przez ,jarzmo prawa”. Antynomiczny król życia i wodzirej nie chce już tylko tańczyć i śpiewać, jak ten Pierwszy, Signor Santo, czyli Szabtaj Cwi - chce krwi, seksu i bijatyki, popędowego vertigo ${ }^{27}$.

Nazywa się więc chamem i prostakiem, ale ma w tym mistyczny cel: jako amurec, am ha'arec, czyli „,człowiek ziemi”, reprezentuje żywioł chtoniczny, zlekceważony przez sublimacyjne religie, i twardo stoi po stronie ,pochwały głupoty", którą Talmud tradycyjnie przypisuje owym wioskowym głupkom. Tak samo zatem jak Kafkowski wieśniak z przypowieści Przed prawem Frank - zadeklarowany amurec - tkwi przed bramą prawa, nie po to jednak, by cierpliwie i pokornie czekać, aż zostanie zaproszony na salon oświeconych, lecz po to, by - jak Jakub - zacząć się mocować (albo jak sam pisze: „borać”) $\mathrm{z}$ anielskim Strażnikiem, a może nawet z Bogiem samym. Raz wszak przytacza niby to wspomnienie $\mathrm{z}$ dzieciństwa, a $\mathrm{w}$ istocie antynomiczną parabolę,

${ }_{26}$ To z pewnością zbieżność przypadkowa, ale bardzo podobnego argumentu użyje Georg W.F. Hegel przeciw Friedrichowi Schleiermacherowi, twierdząc, że gdyby jego definicja religii oparta na prostracyjnej pobożności była prawdziwa, to najbardziej religijnym stworzeniem świata byłby pies służący swemu panu.

27 Zupełnie zatem jak tytułowy Król Życia w pikarejskiej powieści Szczepana Twardocha Król, który - podobnie chyba jak Frank - praktykuje tę formę istnienia spontanicznie $\mathrm{i}$ intuicyjnie. 
w której, jak w krzywym zwierciadle, odbija się opowieść o upragnionym Drzewie Życia i fatalnym nieposłuszeństwie, które pogrążyło Adama w upad$\mathrm{ku}$ :

Gdym był mały, byłem u jednego starego pana, ten miał w swym ogrodzie gruszki osobliwszego smaku i zapachu, dał mi je skosztować i do zjedzenia udzielił. Zapytałem go: Wiele masz drzewek w tym ogrodzie takowych, co taki owoc wydają? Odpowiedział: Mam wiele starych i wielkich drzew, i małych nieco. Mówiłem mu: Ja ci ukradnę frukta z twego ogrodu i gałęzie poucinam, żebym mógł zaflancować je sobie w moim ogrodzie. Mówił pan: jeśli potrafisz ukraść, to twoje będą, ja ci nic złego nie uczynię za to (s. 191).

Po kilkudniowych skomplikowanych podchodach i zapasach, kiedy to mały Frank $\mathrm{z}$ bandą młodocianych chuliganów szturmują mur ogrodu, a starszy pan uparcie wystawia kolejnych strażników, by im to uniemożliwić, w końcu udaje się ukraść cenny frukt fortelem (wszak Jakub Frank to „drugi Jakub"). Wówczas obaj dochodzą do wniosku, że wszystko odbyło się zgodnie z umową - ,i tak pokój był między nami” (s. 191). Zupełnie zatem inaczej niż w oficjalnie wykładanej Księdze Rodzaju, gdzie Adamowi wydaje się, że Bóg zakazuje mu jeść słodkich owoców życia (w istocie żadnego zakazu nie było), następnie zakaz ten łamie (ale tylko częściowo, bo do Ec Chaim nie dociera, zjada jedynie owoc z Drzewa Wiadomości), a potem narzuca sobie poczucie winy, pogrąża się w upadku, śmierci i jarzmie prawa. Tu Bóg sam częstuje swoje ulubione stworzenie, a kiedy to, zasmakowawszy rozkoszy, chce więcej i gryzie rękę, która go obdarowała, Pan tylko się śmieje i wchodzi ze stworzeniem w zakład. Masz tyle sprytu i wytrwałości, by mi wykraść mój skarb? Proszę bardzo, o ile ci się uda - jest twój. Nie po to hodowałem w Edenie te cuda, żeby nikt nie miał z nich pożytku. Nie jestem przecież psem ogrodnika, jak mnie te pomylone religie malują, tylko samym Ogrodnikiem nad Ogrodnikami. Okaż mi jednak na tyle szacunku, by się trochę postarać i o mój drogocenny frukt zawalczyć. W końcu nie ma nic za darmo... I tak, pełni wobec siebie agonicznego respektu, zawierają pokój, w którym zamyka się in nuce figura zbawienia: ludzkość napchana słodkimi klapsami (które w tutejszej, spolszczonej wersji Genesis lepiej symbolizują słodycz życia od biblijnych granatów) żyje w nowym Gan Eden, wyzwolona od błędu niepojętnego Adama, który sprowadził na nas winę, prawo i śmierć, bo nie zrozumiał, że życie to nie owoc zakazany, lecz - wprost przeciwnie - nakaz an y. To przecież „błogosławiony owoc żywota”, który kryje się w „łuspinie” fałszywej i lękliwej pobożności i po który trzeba w końcu odważyć się sięgnąć.

Tak zatem jak chytry Jakub w końcu zwyciężył z Aniołem, tak Frank „drugi Jakub" - ma nadzieję zwyciężyć z Archontem Prawa, uzyskać wielkie błogosławieństwo, odsłonić dotąd nieznane ukryte Imię Boga-Dobrego Ogrodnika i poprowadzić swój lud do pojednania z Ezawem. Celem jest więc 
„otrzeć łzy Ezawa”, jak mówi Zohar ${ }^{28}$, formułując konieczny warunek przyszłego zbawienia: odzyskać utracony witalny wymiar mesjańskiego przesłania, oddać Ezawowi, rudemu kozłowi i „panowi zwierząt”, skradzione mu błogosławieństwo, od czego - jak naucza Frank - rozpoczęło się to największe nieszczęście ludzkości, jakim jest religia instytucjonalna, założona przez Jakuba przemianowanego na Izrael. Misją ,drugiego Jakuba” jest więc naprawić błąd Jakuba pierwszego, który jako Izrael został założycielem judaizmu, odnaleźć mistycznego „drugiego Ezawa” i zwrócić mu jego prawowitą własność: la chaim!, czyli błogosławieństwo życia.

Proste to? Ano proste - jak w pysk strzelił i tego strzelania w pysk w ,gadkach” Franka istne zatrzęsienie, jak na prostaka przystało. Jest też jednak pewna komplikacja, klasyczna pikarejska perypetia, którą prostak musi przeżyć, zanim dotrze do zamierzonego finału. Trzeba bowiem najpierw znaleźć i podnieść $\mathrm{z}$ upadku - Pannę i aby tego dokonać, amurec musi umieć pełzać nisko, z nosem przy ziemi:

Słowo to: Hisnaari meofor kurni - Otrzęśniej się z ziemi i powstań, mówi się do niej. Chociaż ona jest mocą wszech światów, jednakże chce, by ją podnieść; bo ona dotąd prawie leży na ziemi... A te słowa i wykonanie onych, nikomu tylko mnie samemu oddane jest $\mathrm{w}$ ręce (s. 172).

Kim jest ta słodka Dulcynea, Róża, Umiłowana Łania, która upadła? Frank odsłania się tu jednocześnie jako Sancho Pansa, dla którego Dulcynea to najmarniejsza z kurew, i Don Kichot, który wierzy w jej nadziemską czystość: jego Panna jest zarazem upadła i „Najpiękniejsza Między Kobietami”; na pozór w pyle upokorzenia, a w istocie, jak Święta Panienka, w Wieży z Kości Słoniowej.

Panna ta siedzi w wieży, lecz ani ją, ani tej wieży nie widać. Ten tylko polubieniec, gdy ona chce, aby ją widział, to mu zrzuca z okna swój portret, co gdy on znajduje, domyśla się i wie, że tam się ta Panna znajduje (s. 180-181).

Ten portret to, rzecz jasna, częstochowska Madonna. Frank przybywa na Jasną Górę, spogląda w smutne poorane oblicze Czarnej Pani i od razu wie, że zobaczył „Schinę" - „damę” swego serca (s. 190), czyli Szechinę samą, którą musi podnieść z jej mrocznej „,iasności”, aby cały świat mógł ją w końcu ujrzeć ,jaśnie i otwarcie”, „żeby już nic zakrytego nie było” (s. 190). Od dawna przeczuwa, że Polska to kraina wybrana, w której ukrywa się Ezaw, ale teraz, kiedy patrzy w zmętniałe oczy Czarnej Madonny, jest pewien, że to TU.

28 Zohar II, Shemot, $12 \mathrm{~b}$. 
Ezaw chowa się w Często-chowa. Wielkie odkrycie i ujawnienie ma nastąpić w polsko-katolickim Edomie. „W Częstochowie mówił raz Pan: My uganiamy się za portretem" (s. 57).

Czarna Madonna, Matronita, Szechina: dla Franka nie liczy się żadna ortodoksja, którą z upodobaniem gwałci, ani żaden mur getta, który przeskakuje z łatwością łotrzyka rabującego frukta z Zakazanego/Nakazanego Drzewa. Dziecię, które tuli smutna Madonna w ikonicznym stylu theotokos, jest dla niego zarówno Jezusem („Widziałem we śnie Jezusa siedzącego, mającego naokoło siebie księży, nad źrzódłem żywej i czystej wody. Widziałem, że się to źrzódło oddaliło od nich i przyszło do mnie" [s. 180]), jak i małym jeszcze Drugim Ezawem chronionym przez Szechinę, a także - last but not least nim samym: „strasznym niemowlęciem”, które pod nieobecność Ojca, co to wycofał się ze stworzenia w akcie cimcum, widzi siebie w roli nowego fallu$\mathrm{sa}^{29}$. Ten fallus to Jesod: kabalistyczna podstawa stworzenia, zwana też przez Franka Rzeczą, która ma rewolucyjną moc obalenia zakrzepłych stosunków edypalnych, na jakich opiera się wszelkie prawo i porządek: „Gdybym ja odkrył pewną rzecz, to by syn powstał na życie ojca, a ojciec na własnego syna” (s. 192). Poszukiwanie żywota obdarzonego wszechmocą zaczyna więc krążyć wokół potęgi Jesod, która jednocześnie funduje i podważa zakaz kazirodztwa, a tym samym stanowi klucz do boskiej omnipotencji:

To zaś słowo Jessod jest rzecz żywa, a kto jest, co może go ożywić, jak nie ona? W jej ręku może zostać żywym i będzie żyć na wieki. Przez ten Jessod będzie zmartwychwstanie. Jak poruszą tym Jessod choćby od kilku lat zmarłego, to się go ożywi [...] (s. 193).

Wedle Zoharu opuszczona Szechina popada w „wielką gorycz” (s. 194); gdy Jehowa zostawia swą oblubienicę i nie odbywa z nią regularnie stosunku, kosmoerotyczny porządek świata ulega załamaniu i całe życie więdnie. Dlatego też chasydzi w piątkowy wieczór śpiewają hymn do Szechiny, by ta nie ustawała $\mathrm{w}$ próbach odnalezienia swego ukochanego, i sami sumiennie oddają się fizycznej miłości, by do niej boską parę sprowokować. Frank nie ustaje w chełpliwych opowieściach o swoim kutasie i ciągłym obnażaniu się ku uciesze panien (,W Iwaniu widziały u mnie kobiety trzy przyrodzenia!” [s. 64]), w czym powołuje się na samego króla Dawida, który raz tak się zapamiętał

29 „Straszne niemowlę” - wspaniały termin Melanie Klein - pasuje do Franka jak ulał, może też dlatego, że da się w nim odnaleźć echa sytuacji opisywanej przez kabalistów: relacja męskiego niemowlęcia do matczynego ciała, do którego czuje się ono uprawnione pod nieobecność ojca (ten jeszcze w diadyczną relację nie interweniuje) i które daje mu fantazmatyczne poczucie wszechmocy, stanowi psychoanalityczny wariant relacji młodego adepta kabały do Szechiny, opuszczonej przez swego boskiego oblubieńca, która, jak mu się narcystycznie roi, w akcie substytucji wyposaża go w magiczno-mesjańskie moce. 
w religijnej ekstazie, że tańczył radośnie nagi od pasa w dół. Jednocześnie jednak upomina swoich słuchaczy, by nie brali jego pornograficznych ,gadek” zbyt dosłownie: „Jakże możecie mówić, że ten Jessod jest piękną rzeczą? Czyliż się można odkryć przed królem, panem wielkim? Wszak u konia jest większy, i cóż stąd?" (s. 193). Seksualność jest tu więc także figurą, która dopiero zapowiada przyszłą chwałę Rzeczy, nagość zaś antycypuje „nowy strój”, ową szatę Ezawową, która na pozór jest skórą zwierzęcą, w istocie jednak jest jak ,zbroja” (s. 313), nieodróżnialna od nowego - już niezniszczalnego i nieśmiertelnego - ciała. Pleroma pierwotnego Boga bez kresu i bez nazwy, czyli Ein-Sof - tej Reczy, das Ding, której „nic nie brakuje”, bo jest zawsze „W całości” (s. 392), i której odpowiada najwyższa tajemna wiedza, Daas jest, zupełnie jak później u Sigmunda Freuda, tyleż seksualnością, co jednocześnie czymś więcej, jakimś je-ne-sais-quoi życia maksymalnie powiększonego, które przedstawia się jako ,nieposzkodowane” i odporne na wszelki ubytek, łącznie ze śmiercią ${ }^{30}$. Dojść do tego żywota - które Hegel w swoich refleksjach o chrześcijaństwie nazywał unverletztes Leben, Derrida zaś za nim la vie indemne - jest jedynym dążeniem Franka, ale też w ogóle jedynym pragnieniem wszystkiego, co żyje ${ }^{31}$.

Tylko Frank jednak widzi się w roli prawdziwego pomazańca, zdolnego odnaleźć Rzecz i zdobyć Pannę, która jest „bramą do życia wiecznego”. Wszyscy przed nim - Abraham, Jakub, Mojżesz i Jezus - sromotnie przy tym zadaniu polegli. Abraham, ponieważ nie doszedł do Egiptu; Jakub, ponieważ dał początek judaizmowi jako opresyjnej religii prawa; Jezus, ponieważ uległ Bogu-Ojcu - którego Frank wyobraża sobie, w zgodzie z marcjońskimi trendami obecnymi u bałkańskich bogomiłów, jako mrocznego archonta i Króla Śmierci (Melek ha-mavet) - zgodził się umrzeć na krzyżu i przenieść obietnicę żywota wiecznego na tamten świat. Frank tymczasem sądzi, że obietnicę tę

30 O kabalistyczno-teologicznych konotacjach Freudowskiej „seksualności” pisałam wyczerpująco w moim Errosie, gdzie tytułowy „Erros” funkcjonuje właśnie jako figura „Życia powiększnego”. Zob. A. Bielik-Robson, Erros. Mesjański witalizm i filozofia, Kraków 2014, a zwłaszcza rozdział Niepokoje młodego libido: Freud, s. 225-349.

31 Nie sposób oprzeć się wrażeniu, że to, co Derrida w Wierze $i$ wiedzy nazywa aporetycznym double bind wszelkiej religii jako jednocześnie mesjańskiej religii życia, dążącego do samopowiększenia i wzmożenia tu i teraz, i kultowej religii śmierci projektującej transcendentną figurę Absolutu jako „więcej-niż-życie”, jest bardziej sofistykowaną wersją poglądów samego Franka, który wszędzie dopatruje się podwojenia; tam więc, gdzie pierwszy Jakub pobłądził, on jako drugi Jakub błąd naprawi, wyzwalając boski „dar życia” z oków religii instytucjonalnej. Nie mówiąc już o tym, że gra dwóch hebrajskich słów wymawianych niemal tak samo, dat i da'at - gdzie to pierwsze to dat szel Edom, ,religia Edomska", czyli upadły polski katolicyzm, kwintesencja skorupy-łuspiny, a to drugie to da'at ha kodesz, święta gnoza, czyli wiedza tajemna - to najlepsza ilustracja Derridiańskiej zasady differance: różnicy ukrytej, tkwiącej niczym sekretne jądro w hupinie codziennej mowy. Por. J. Derrida, Wiara i wiedza. Dwa źródła ,religii” w obrębie samego rozumu, przeł. P. Mrówczyński [w:] J. Derrida, G. Vattimo et al., Religia, Warszawa 1999, s. 64. 
zrealizuje tu i teraz, tak jak miało być na początku; kiedy nadejdzie prawdziwe stworzenie - w całości i bez braku - życie stanie się niezniszczalne, wolne od tej ostatecznej kary za grzech, jaką jest śmierć.

Tak bóg śmierci rzecze mu: Mów uczniom twoim, że żywot wieczny będzie na drugim świecie, ale nie na tym tu świecie. Dlatego stoi w pacierzu: A po śmierci żywot wieczny [...]. [Stąd - dop. A.B.R.] chrześcijanie umierają z radością, bo mówią, że każdy ma cząstkę swą w niebie u Jezusa Syna, który siedzi na prawicy Boga. Dlatego poszedł Jezus z niczym z tego świata i tamże wpadł. Potem znowu wywołano w niebiesiech: Kto, kto jest ten, co chce iść? Ozwał się Adonajni Sabathaj Cewi: Ja pójdę. Też poszedł, nic nie przyniósł i nie dokończył. Potem mnie posłano, abym sprowadził żywot wieczny na ten świat. Dano mi też moc, abym wam pokazał moc, którą mi dano [...] (s. 391) 32. $^{32}$

Kiedy więc, mniej więcej w tym samym czasie, Fryderyk Wilhelm II Pruski sztorcuje swoich żołnierzy, niezbyt chętnych, by składać życie w ofierze na polu walki - „,o wy, psy, chcielibyście żyć wiecznie?” - Frank mówi: ano tak, my, nędzne psy, przybłędy ze społecznych nizin, chamy pogardzane przez panów tego świata, dokładnie tego chcemy. Oto nasza rewolucja prostaków.

Podobnie więc jak narracja pikarejska to uświatowiona, zdesublimowana i podlana komicznym sosem baśń inicjacyjna, gdzie ostatecznym skarbem okazuje się „życie w całości”, tak też „gadki” Franka opisują zawiłe labirynty komplikacji, z której to gęstwy prześwituje tu i ówdzie nadrzędny cel: zdobycie Rzeczy. Nasz antynomiczny nurek, Mesjasz odwrócony, musi zanurzyć się

32 Maranizm Franka to chrześcijaństwo w drugim wydaniu, znacznie poprawione albo, jak by powiedział Moses Hess, „odmłodzone”. Frank zgadza się z Pawłem, że „smutek tego świata sprawia śmierć” (2 Kor 7,10), bo „właśnie w samym sobie znaleźliśmy wyrok śmierci" (2 Kor 1,9) jako znamię wewnętrznego wybrakowania, które litera prawa tylko podkreśla - „litera bowiem zabija, Duch zaś ożywia” (2 Kor 3, 6). Gotów jest także przyznać, że ,jako ostatni wróg, zostanie pokonana śmierć (1 Kor 15, 26), otwierając nas na żywot wieczny. Nie godzi się jednak na deprecjację życia cielesnego, ziemskiego, do jakiej Paweł, „chemicznie czysty spirytualista” (jak go nazywał Gershom Scholem), nas namawia. Choć więc motyw ,nowego odzienia” również pochodzi od Pawła, to u Franka przybiera zupełnie odmienną, dosadnie doczesną postać: staje się „szatą Ezawa”, wspaniałą zwierzęcą skórą, która okrywa ludzką nagość będącą symbolem dotychczasowego zawstydzającego braku: „Tak przeto teraz wzdychamy, pragnąc przyodziać się w nasz niebieski przybytek, o ile tylko odziani, a nie nadzy będziemy. Dlatego właśnie udręczeni wzdychamy, pozostając w tym przybytku, bo nie chcielibyśmy go utracić, lecz przywdziać na niego nowe odzienie, aby to, co śmiertelne, wchłonięte zostało przez życie. A Bóg, który nas do tego przeznaczył, dał nam Ducha jako zadatek. Tak więc, mając tę ufność, wiemy, że jak długo pozostajemy w ciele, jesteśmy pielgrzymami, z daleka od Pana” (2 Kor 5, 2-6). Wszystkie cytaty z listów Pawła za Biblia Tysiąclecia. 
jeszcze głębiej w mroki przeciwności (aversidados). Ażeby Reczy dosięgnąć, nie wystarczy pełzać ,jak wąż” po ziemi - w jej prochu leży upadła Szechina - trzeba zejść jeszcze niżej, w ciasne podziemia „dubeltowej jaskini”:

Od początku świata jest rzecz schowana w dubeltowej jaskini, dlatego tam pogrzebiony jest Adam pierwszy [...]. Oni [patriarchowie - dop. A.B.R.] tam poszli przez śmierć, a my potrzebujemy pójść tam i stamtąd rzecz pewną podnieść (s. 180).

Jak jednak zejść na samo dno jaskini i nie dać się zabić? Jak przeżyć, będąc prorokiem w obcym kraju, który wybrało się z powodu jego przepastnej duchowej pustki? Jak „flancować” ducha w tej wyschłej pustyni, którą chce się zamienić w bujną winnicę do osobistego „deptania”? Mało prawdopodobne, by Frank w ogóle słyszał o Platonie, ale jego instynkt przeżycia w najmniej sprzyjających okolicznościach polskiego Edomu daleko przerasta survival skills Sokratesa, dla którego próby oświecania mieszkańców z dna jaskini skończyły się tragicznie. Frank to amurec-prostak, dla którego przeżycie jest główną namiętnością; przeżycie, z którego jest nieskończenie dumny i które objawia swym słuchaczom jako znak wybraństwa. Rozliczne „gadki” w pikarejskim stylu ,zabili go i uciekł”, których jedynym tematem jest delektowanie się własnym sprytem - drugim wcieleniem tej samej chytrości, która wywabiała z każdej opresji biblijnego Jakuba - mają dowieść zainteresowanym, że oto stoi przed nimi lucky man na miarę Króla Dawida: tak samo rudowłosy, jurny i żywotny, naznaczony wielkim szczęściem, które ratuje go z wszelkich „ciasności” ${ }^{33}$. Te „ciasności”, które pojawiają się w Słowach Pańskich na każdym kroku, to rzecz jasna spolszczone micraim: ciasna i ciemna kraina ${ }^{34}$, przypominająca mroczną wąską jaskinię, z której trzeba wyjść na światło i powietrze, ale i kanał rodny, przez który trzeba się przecisnąć na świat, by się narodzić - i wreszcie zacząć żyć.

\section{Życie odnalezione, czyli łotrzykowska teologia}

Jeśli więc istotnie Benjaminowska metafora hagady podnoszącej łapę - rudą i włochatą, jak u Ezawa - na porządek halachy znajduje gdzieś swoje pełne dosłowne wcielenie, to właśnie w łotrzykowskich „gadkach” Franka. Haga-

33 Lucky man to termin, którym Dawida określa Biblia Króla Jakuba: na temat owego szczęścia, które staje się widomym znakiem wybraństwa i ,większego życia”, zob. przede wszystkim: H. Bloom, The Book of J, New York 1990, s. 230.

34 Micraim to hebrajska nazwa Egiptu, czyli - w notacji Franka, gdzie wszystko ulega ambiwalentnemu ,podwojeniu” - tego „drugiego”, złego, Egiptu, symbolizującego niewolę i uciśnienie samej tylko pokrywy. 
da Franka to szekspirowskie ,życie jako opowieść idioty, pełna wściekłości i wrzasku", która jednak nie jest ,nic nie znacząca" ${ }^{35}$. Za każdym razem nasz prostak-idiota podkreśla, że w tej głupocie jest metoda - metoda antynomiczna, która pozwala wyłuskać ukryte sedno z ,łuspiny”:

Ziele żywe w śmiertelnym się zamyka (s. 57).

W każdym miejscu łuspina poprzedza owoc. Widzicie sami, że wszyscy wołają ją: Wieczna Panna. Mówią na nią, że ona Królowa Niebieska [...]. Ona jest ta, co poprzedza owoc, który ma wyjść na świat i przed nim będą klęczeć wszyscy królowie ziemscy na jawie (s. 279).

Fragment ten - kolejny z obsesyjnie licznych poświęconych Najświętszej Panience, która dziewiczo porodziła syna - dobrze pokazuje, jak skomplikowana jest relacja między łuspiną a owocem, pokrywą a ziarnem, skorupą a iskrą albo (w poetyckim języku wieszcza inspirowanego frankizmem) plugawą skałą a ognistą lawą. Najciekawsza część nauk Franka to „boranie się” z tą właśnie, wyjątkowo gęstą dialektycznie kwestią.

Zgodnie z obrazem kabalistycznym skorupa (kelipa) to więzienie iskry (nicoc), czyli źródło materialnej opresji dławiącej resztki boskiego światła rozproszonego w stworzeniu. Pod wpływem skorup iskry ulegają deformacji i przygasają, wegetując uśpione w stanie „,ciasności”, przyduszone i zniekształcone pod ciężarem cielesnej pokrywy. Jak by z kolei powiedzieli Nicolas Abraham i Maria Torok, dwoje żydowsko-węgierskich psychoanalityków, którym nauki kabalistyczne nie były całkiem obce, esencje te śpią snem podobnym śmierci złożone w krypcie ciała, którego skorupa jest jednocześnie nagrobkiem: znakiem, że tu oto spoczywa imię, które tylko wtajemniczeni potrafią odszyfrować ${ }^{36}$. Jednocześnie jednak „łuspina” (ecorce) nie tylko tłamsi, ale także ochrania; dzięki niej sedno, czyli nux (noyau) może się przechować w niesprzyjających okolicznościach, przetrwać, przetrzymać próbę. Krypta zatem zarówno przygniata, jak i ocala złożone w niej delikatne jądro, które umarłoby wystawione na bezlitosne ,światło zwykłego dnia”. Z dialektyki tej wynika więc, że nieuchronna deformacja byłaby także konieczną ceną, jaką sedno/iskra musi zapłacić za możliwość przetrwania: „łuspina poprzedza owoc" - co oznacza, że jest ona jednocześnie kamiennym nagrobkiem, który umartwia, i cielesną otuliną, która żywi. Gdyby spojrzeć na „,portret Panny”,

35 „Life is a tale/ Told by an idiot, full of sound and fury/Signifying nothing” (W. Shakespeare, Mackbeth, akt 5, scena 5).

36 Na temat kryptonimii i kryptoforii zob. N. Abraham, M. Torok, Wolf Man's Magic Word: A Cryptonymy, transl. N.T. Rand, Minneapolis 1986 (a zwłaszcza przedmowę Derridy pt. Fors); w kwestii relacji między łupiną a owocem zob. iidem, The Shell and the Kernel, transl. N.T. Rand, Chicago 1994. 
czyli obraz częstochowskiej Madonny, nieuprzedzonym okiem - okiem idioty, szaleńca, świętego prostaka - zobaczylibyśmy właśnie to zawrotne ,podwojenie": to portret trumienny, gdzie Czarna Pani, z której uszło życie, tuli w ramionach martwe niemowlę, a zarazem obraz matki, która właśnie wydała „błogosławiony owoc żywota swego”, nową nadzieję ludzkości.

Co więc dzieje się z iskrą, gdy ją na powrót wyłuskać? Czym wówczas się staje? Jaka róża mistyczna, jaka Szoszana wyrasta z tego ziarna, które obumarło, ale i przetrwało w anabiotycznym obumarciu? „Czyn drugi będzie większy od pierwszego" - mówi Talmud ${ }^{37}$ i zdanie to zawsze było czytane przez kabalistów jako zapowiedź zbawienia, które przerośnie glorię pierwszego stworzenia z czasów Edenu: tikkun nie ma być zwykłym powrotem do nieskażonej pierwotnej kreacji, lecz czymś więcej - Nową Różą. Inaczej więc niż w Miłoszowym wyobrażeniu zbawienia przez apokatastazę - gdzie świat cały, jak w odwróconej historii Benjamina Buttona, nagle zawraca do czystego zwartego ziarna, nux - tu ziarno, jednocześnie odmienione i uchronione przez łuspinę, ma wydać nowy kwiat (mistyczną różę) i owoc (nowe życie): oto tajemnica powtórzonego stworzenia. Nie będzie więc tak jak u Miłosza: „Nagle umilknie warsztat demiurga. Nie do wyobrażenia cisza. I forma pojedynczego ziarna wróci w chwale" ${ }^{38}$. Nie, to będzie zupełnie inny koniec świata: warsztat demiurga nie tylko nie umilknie, ale hałas - ,wrzask” jeszcze się natęży i nie będzie to czysta robota przebiegająca w ascetycznej ciszy. Przeciwnie, nastąpi wybuch energii dotąd nieznany, kiedy całe to życie, dotąd tłumione pod pokrywami, eksploduje jak bomba z opóźnionym zapłonem. Pikarejska formuła, w której Frank opowiada swoje życie - już wychylające się z otulin „łuspiny”, by pokazać, do czego jest zdolne; już odrywające się od piersi tradycji i religii, by dorosnąć i stanąć na własnych nogach ${ }^{39}$ - stanowi zatem zapowiedź-proroctwo nowego łotrzykowskiego stworzenia, gdzie

37 Por. traktat Ta'anit, 24 a.

38 C. Miłosz, Gdzie wschodzi słońce i kędy zapada [w:] idem, Gdzie wschodzi słońce $i$ kędy zapada i inne wiersze, Kraków 1980, s. 141.

39 J. Derrida, Rogues..., s. 65. Motyw stawania na nogi, łapania równowagi i stabilizowania „chodu” jako symbol duchowego dojrzewania przewija się przez całą księgę: „Jak będziecie znali i rozumieli chód Abrahamowy, iż on jest pierwszą filarą, także chód Izaaka i Jakóba, to wiedzieć będziecie, co się działo i dziać ma aż do końca, tyle że się świat jeszcze chwieje, bo ich jest tylko trzy nóg, póki nie przyjdzie czwarty, i to noga czwarta, wtenczas świat już stałym i niewzruszonym zostanie” (s. 161). Podobnie zatem jak u Agambena, którego inspirowana frankizmem wizja Mesjasza zaopatruje go w „Zwierzęcą głowę”, tu gwarantem mesjańskiej „stałości” przyszłego świata mają być cztery nogi mocno stojącego na ziemi Ezawowego zwierzęcia. Por. G. Agamben, The Open. Man and Animal, transl. K. Attell, Stanford 2004, s. 2. Przy okazji jakoś nie sposób nie wspomnieć tu o słynnych „dwóch nogach” Lecha Wałęsy (nomen omen) i jego innych mądrościowych „gadkach”, podawanych ku rozpaczy światowej dyplomacji w stylu uparcie ,amurecowym”. 
uwolnione życie da wszystkiemu nieźle popalić, bo będzie jak kula energii tocząca się przez świat, któremu nie pozostanie już nic innego, jak tylko poddać się i ulec.

W taki antynomiczny sposób György Lukács sportretował Księcia Myszkina, którego Fiodor Dostojewski nie przypadkiem nazwał idiotą ${ }^{40}$. Na pozór niewiele łączy arystokratycznego idiotę z naszym idiotą-prostakiem, oprócz tego, że jako ,gnostycy czynu"41 obaj noszą w sobie to wyższe życie, które już się przebudziło i teraz wchodzi w antytetyczne reakcje ze światem w jego zakrzepłym status quo. Jednak wzorcowym wcieleniem tej antytezy jest pikarejski łazik-łotrzyk, a tym samym jest on także proroczą zapowiedzią Derridiańskiego farmakonu, życiodajnej trucizny, która przenika i drąży zakrzepłą rzeczywistość, już na dwa stulecia przed Marksem realizując jego rewolucyjny program „odparowywania wszystkiego, co stałe” i ,profanowania wszystkiego, co święte": uwalnia życie, które upłynnia alles Ständische und Stehende i podkopuje uświęcone prawem boskim hierarchie. Jak zaś twierdzi Derrida - kolejny (i jak na razie ostatni) prorok w tej osobliwej sekwencji mesjanizmu chuligańskiego - przyszłość należeć będzie do voyoucracy: „demokracji łotrzykowskiej”, w której to nieskończenie sprytny i żywotny Lazarillo de Tormes, skrzyżowany z Sancho Pansą, na zawsze już uwolnionym od chimer duchowej donkiszoterii, stanie się ostatecznym politycznym suwerenem.

Ukrytą agendą dekonstrukcji - jej najgłębszą sekretną Rzeczą - byłaby więc tajna operacja, wcale nie tak niepodobna do rewolucyjnych aspiracji samego Franka, której kryptonim mógłby brzmieć: Lazarillo Unbound.

Voyoucracy to skorumpowana i korumpująca władza ulicy, władza nielegalna i pozaprawna, która zrzesza - a tym samym nadaje zorganizowaną, mniej lub bardziej tajną formę czegoś w rodzaju wirtualnego państwa - wszystkich tych, którzy reprezentują zasadę nieporządku: zasadę nie tyle anarchicznego chaosu, ile nieporządku ustrukturowanego, zasadę spisku i konspiracji, zasadę umyślnej obrazy ładu publicznego. [...] Rząd łotrzyków to zatem zasada nieporządku i w tym sensie zagrożenie dla ładu publicznego, ale jako kracja przedstawia sobą coś więcej niż tylko zbiór poszczególnych voyous. To zasada nieporządku jako ładu tymczasowego czy zastępczego (jak to ma miejsce w rozmaitych tajnych stowarzyszeniach, sektach religijnych albo wolnomularstwie $)^{42}$.

40 G. Lukács, On Poverty of Spirit. A Conversation and A Letter, transl. J.T. Sanders, „The Philosophical Forum. The Quarterly” 1972, no. 3-4, s. 375.

41 Ibidem.

42 J. Derrida, Rogues..., s. 65. Derrida znał frankizm wyłącznie pośrednio, za sprawą Scholema, którego czytał uważnie już w latach sześćdziesiątych (wyraźny ślad tej lektury zawiera „kabalistyczny esej” poświęcony Nombres Philippa Sollersa zatytułowany Dissemination), ale jego własne późniejsze eksperymenty z ,maranizowaniem” zbliżają go do Franka mocą tej samej marańsko-mesjańskiej logiki w łonie teologii doczesności. W Circonfession, „wyznaniu obrzezanym”, Derrida określa siebie mianem „marana francuskiej 
W cytowanej powyżej książce Derridy, stanowiącej pochwałę łotrzykowskiego półświatka żyjącego na krawędzi prawa jako zarodka-ziarna demokracji przyszłości, która w końcu strząśnie z siebie wertykalne hierarchie i zstąpi w horyzontalny żywioł życia, pojawia się również inny termin, synonimiczny z voyoucracy, czyli „rządami łotrzyków”: „kora polityczności”. Kora - platońska niańka wszystkich rzeczy utożsamiona z wielkim naczyniem (pandechos) - to najniższy byt w metafizycznej hierarchii, o ile w ogóle jeszcze przysługuje mu/jej zaszczytne miano istnienia. To same doły ontologiczne, którym w tradycji hebrajskiej odpowiada status pierwotnych wód chaosu, czyli tohu $v a$-vohu, a także - na planie teologiczno-politycznym - erev rav, czyli ,wieloplemienny tłum", nieobjęty ścisłym prawem i tożsamością ${ }^{43}$. W wizji Derridy jednak ta metafizyczna mierzwa staje się Matką Wszystkich Łotrów, postacią charakterystycznie pikarejską: jej wcieleniami są zaś zarówno prostytuująca się rodzicielka pierwszego Łazika, jak i Matka Courage Bertolta Brechta czy Smurf z Królestwa Zwierząt (jeśli ktoś ogląda seriale HBO). Wydaje ona na świat kolejnych voyous poza wszelką ontologiczną ortodoksją: istoty krzywe z urodzenia, zdewiowane, o mętnym pochodzeniu i społecznych statusie, ale za to żywe i żywotne, niesione - jak by z kolei powiedział Marks - kinetyczną energią uwolnioną z hierarchicznego zakrzepnięcia. W Derridiańskim opisie kory wyraźnie zatem słychać echa Frankowej wizji pierwszego i jedynie prawdziwego Boga, życiodajnego (a może życiodajnej?) Ein-Sof:

Ta afirmacja [Derrida pisze o swym wyborze platońskiej kory - dop. A.B.R.] jest aktem mesjańskiej wiary, a jednocześnie wiary niereligijnej i bez konkretnego mesjanizmu. [...] Moja reinterpretacja Timajosa nazwała korę (która oznacza: lokowanie, miejscowienie, przestrzenny interwał) tym innym miejscem pozbawionym wieku, innym ,umiejscawianiem”, odbywającym się na „pustyni w pustyni”, innym uprzestrzennianiem, jeszcze zanim wyłoni się kosmos [...], zanim jeszcze pojawi się jakikolwiek antropo-teologiczny dogmatyzm i historyczność. [...] Tym, co zezwala na takie właśnie zajmowanie miejsca, bez gruntu, racji i podstawy, jest właśnie kora. Kora byłaby tym, co czyni i daje miejsce: byłaby czystym pozwoleniem na nadejście wydarzenia, w niczym się doń nie dokładając ${ }^{44}$.

kultury katolickiej”, który nieustannie oscyluje między dwiema tożsamościami - żydowską i chrześcijańską - nigdy w pełni nie przyjmując żadnej z nich. Zob. J. Derrida, Circumfession [w:] J. Derrida, G. Bennington, Jacques Derrida, Chicago 1993, s. 160.

43 Por. P. Maciejko, Wieloplemienny tlum. Jakub Frank i ruch frankistowski 17551816, przeł. J. Chmielewski, Gdańsk 2015. To Maciejce zawdzięczamy „feminizującą” interpretację frankizmu, która podkreśla zbawczą rolę żeńskich figur - Panny/ Matronity/ Szechiny - i twierdzi wręcz, że pod koniec życia Frank nie uważał się już za mesjasza, lecz rolę tę scedował na swoją córkę Ewę.

44 J. Derrida, Rogues..., s. xiv. 
Tak zatem jak Ein-Sof usuwa się, by dać miejsce „krzywemu wydarzeniu życia" ${ }^{45}$, w niczym tego życia nie obciążając - tak też Derridiańska kora „czyni miejsce”, a tym samym „daje żyć” (zgodnie z naczelną zasadą epoki nowo-żytnej: leben-lassen, let-live), niczego nie oczekując za-miast, czyli w miejsce tak uczynionego miejsca. I tak jak dla Franka tuziemskim przebłyskiem-przypomnieniem Ein-Sof jest „bezwietrzny”, cichy i nieporuszony Egipt, oblany życiodajnym Nilem, tak dla Derridy jest nim absolutna cisza „pustyni w pustyni” jako jedyna przywodząca na myśl Boga Bez Imienia, którego wyłącznym - paradoksalnym, bo nietożsamościowym - ukrytym mianem okazuje się makom: „to inne miejsce pozbawione wieku”. I tak jak Ein-Sof nie ma płci, będąc tyleż „bez kresu”, co bez jakiejkolwiek właściwości i tożsamości, choć zarazem jest w retoryce Franka przeciwieństwem „tego jednego", co to się nazwał i obdarzył kosmicznym fallusem - tak też u Derridy kora, choć poza wszelką de-finicją i de-nominacją, jest raczej macierzą, której łagodne oddziaływanie rozkłada hierarchiczne szyki fallogocentryzmu:

Jakżeście to myśleli, że Mesjasz będzie mężczyzna? To być żadną miarą nie może, bo gruntem jest Panna. Ona to będzie tym prawdziwym Mesjaszem. Ona prowadzić będzie wszystkie światy, bo wszystkie zbroje oddane w jej ręce. Co mówiono o Dawidzie, i owym Pierwszym [że „potajemnie byli kobietami” - dop. A.B.R.], oni tylko przyszli, aby pokazać drogę do niej, ale oni żadnej rzeczy nie skończyli. Zważcie i teraz: kasują religię jego [czyli „Jednego” - dop. A.B.R.], ale jej honoru nie naruszają bynajmniej (s. 313).

Zakończyć Rzecz to zatem „skasować religie” - wszelkie tradycje i denominacje uprawiające kult widzialnego imienia - a jednocześnie ocalić „honor” tej, której paradoksalnym, niewidzialnym, głęboko ukrytym Imieniem-bez-Imienia jest „miejsce” wydające „błogosławione owoce”. Skasować religię oznacza więc jednocześnie spełnić jej mesjańską obietnicę, czyli - wres zc i e, a zatem w tej reszcie „czasu, która pozostanie" ${ }^{46}$, po eonach naznaczenia brakiem, grzechem pierworodnym, winą i śmiercią - doprowadzić nas wszystkich do żywota. Ale sztuka ta - ten ostateczny majstersztyk - udać się może tylko pikarejskiemu tricksterowi, którego „burzliwe życie” - tak pełne „wzlotów i upadków”, „,blasków i cieni”, ,przygód i przypadków”, że przepełnia i przelewa każde naczynie tożsamości - jest ruchomym ziemskim obrazem bezkresnej Ein-Sof. Powieść łotrzykowska byłaby więc, jak w parodii Platona,

45 „Ten rys dewiacji w każdej żywej rzeczy,/ Co jest jej życiem ocalonym, próbą, by się narodzić/ Przeżyciem, by się narodzić - wydarzeniem życia” (W. Stevens, A Discovery of Truth [w:] idem, Opus Posthumous. Poems, Plays, Prose, London-New York 1990, s. 123).

${ }^{46}$ Por. G. Agamben, Czas, który zostaje. Komentarz do „Listu do Rzymian”, przeł. S. Królak, Warszawa 2009. 
swoistym ,ruchomym obrazem wieczności”: pierwotnej boskiej macierzy bez kresu i bez wieku, Boga ,prawdziwego", ale może z tego powodu niepozbawionego, jak życie samo, cech komicznych ${ }^{47}$.

„Kto nie dotknął ziemi ni razu, ten nigdy nie może być w niebie”. Kto zaś dogłębniej poznał życie, blisko się ziemi trzymając, niż nieutrudzony i niespożyty prostak i łotrzyk Jakub Frank?

\section{Bibliografia}

Abraham N., Torok M., The Shell and the Kernel, transl. N.T. Rand, Chicago 1994.

Abraham N.,Torok M., Wolf Man's Magic Word. A Cryptonymy, transl. N.T. Rand, Minneapolis 1986.

Agamben G., Czas, który zostaje. Komentarz do „Listu do Rzymian”, przeł. S. Królak, Warszawa 2009.

Agamben G., The Open. Man and Animal, transl. K. Attell, Stanford 2004.

Agamben G., Potentialities. Collected Essays in Philosophy, transl. D. Heller-Roazen, Stanford 2000.

Anonim, Żywot Łazika z Tormesu, przeł. M. Mann, Warszawa 1959.

Benjamin W., Selected Writings, vol. 3, ed. M.W. Jennings, Cambridge-Massachusetts 2006.

Berman M., ,Wszystko, co stałe, rozpływa się w powietrzu”. Rzecz o doświadczeniu nowoczesności, przeł. M. Szuster, wstęp A. Bielik-Robson, Kraków 2006.

Biblia Tysiaclecia

Bielik-Robson A., Erros. Mesjański witalizm i filozofia, Kraków 2014.

Bloom H., The Book of J, New York 1990.

47 Czy coś podobnego nie chodzi po głowie Heglowi, kiedy w końcówce Fenomenologii ducha podaje swoją własną parafrazę platońskiego toposu ,ruchomego obrazu wieczności" jako pochodu ducha przez dzieje, który wyświetla się w serii przedziwnych obrazów, jakby w jakimś metafizycznym projektorze? Ta duchowa kinematografia ukazująca historię jako niemy film, „wolno się poruszającą galerię obrazów” (Hegel, rzecz jasna, jeszcze nie znał wynalazku braci Lumière), ma jednocześnie charakter tragiczny - dla Hegla historia jest „drogą krzyżową ducha absolutnego" - i komiczny, który żywo przypomina pikarejskie powieści pełne niespodziewanych zwrotów akcji, kiedy to duch wciela się w poszczególny ludzki podmiot i staje się duchem subiektywnym - czymś zatem, co Nietzsche nazywa „żywym głupcem”. „Naiwny”, dziecinny i prosty, ale jednocześnie sprytny Jakubową „,chytrością" duch chłonie swój nowy świat i szybko uczy się życia, by już za chwilę dziarsko przedzierać się przez oporną materię i na końcu osiągnąć swoje: „W tym nowym świecie duch musi w sposób naiwny zaczynać zawsze od początku, od bezpośredniości tego świata, musi pozwolić się znowu przez ten świat wychować, jak gdyby wszystko to, co było dotychczas, dla niego przepadło i jak gdyby nic nie nauczył się z doświadczenia duchów poprzednich" (G.W.F. Hegel, Fenomenologia ducha, t. II, przeł. A. Landman, Warszaw 1965, s. 427-428). 
Derrida J., Circumfession [w:] J. Derrida, G. Bennington, Jacques Derrida, Chicago 1993.

Derrida J., Rogues. Two Essays on Reason, transl. P.-A. Brault, Stanford 2005.

Derrida J., Wiara i wiedza. Dwa źródła ,religii” w obrębie samego rozumu, przeł. P. Mrówczyński [w:] J. Derrida, G. Vattimo et al., Religia, Warszawa 1999.

Doktór J., Nieznośny ciężar milczenia [w:] J. Frank, Słowa Pańskie. Nauki Jakuba Franka z Brna i Offenbachu, wstęp i oprac. J. Doktór, Warszawa 2017.

Escarmant Ch., La lettre marrane de Rabelais, „Pardès. Etudes et culture juives” 2000, no. 29 (Le Juif caché. Marranisme et modernité, ed. S. Trigano).

Faur J., Don Quichotte: un talmudiste au passé souillé, „Pardès. Etudes et culture juives" 2000, no. 29 (Le Juif caché. Marranisme et modernité, ed. S. Trigano).

Frank J., Rozmaite adnotacje, przypadki, czynności i anegdoty pańskie, red. J. Doktór, Warszawa 1996.

Frank J., Słowa Pańskie. Nauki Jakuba Franka z Brna i Offenbachu, wstęp i oprac. J. Doktór, Warszawa 2017.

Hegel G.W.F., Fenomenologia ducha, t. II, przeł. A. Landman, Warszaw 1965.

Hess M., The Holy History of Mankind and Other Writings, przeł. S. Avineri, Cambridge 2004.

Lipszyc A., Czerwone listy. Eseje frankistowskie o literaturze polskiej, Kraków 2018.

Lukács G., On Poverty of Spirit. A Conversation and A Letter, transl. J.T. Sanders, „The Philosophical Forum. The Quarterly” 1972, no. 3-4.

Maciejko P., Wieloplemienny tłum. Jakub Frank i ruch frankistowski 1755-1816, przeł. J. Chmielewski, Gdańsk 2015.

Majmon S., Autobiografia, przeł. L. Belmont, red. B. Szwarcman-Czarnota, P. Paziński, Warszawa 2007.

Majorino G., At the Margins of the Renaissance. Lazarillo de Tormes and the Picaresque Art of Survival, Pennsylvania 2003.

Marks K., Engels F., Manifest komunistyczny, przeł. W. Piekarski [w:] eidem, Dzieła, t. IV, Warszawa 1962.

Miłosz C., Gdzie wschodzi słońce i kędy zapada i inne wiersze, Kraków 1980.

Nietzsche F., Poza dobrem i złem, przeł. G. Sowinski, Kraków 2001.

Ochocki A., Trzy opery albo podmiotowość komiczna, Warszawa 2003.

Scholem G., The Messianic Idea in Judaism. And Other Essays on Jewish Spirituality, New York 1995.

Stevens W., A Discovery of Truth [w:] idem, Opus Posthumous. Poems, Plays, Prose, London-New York 1990.

Yovel Y., The Other Within. The Marranos: Split Identity and Emerging Modernity, Princeton-Oxford 2009.

Yovel Y., Spinoza and Other Heretics. The Marrano of Reason, Princeton, N.J., 1989. 